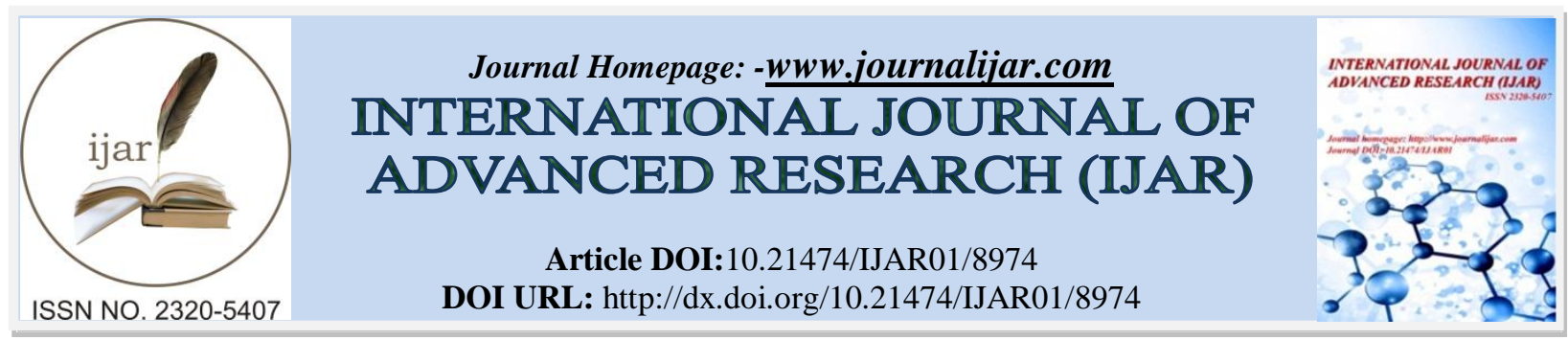

RESEARCH ARTICLE

\title{
BARRIERS IN THE IMPLEMENTATION OF SCHOOL-BASED ANTI-BULLYING INTERVENTION PROGRAMS AND STRATEGIES IN PUBLIC SECONDARY SCHOOLS IN A CERTAIN DIVISION IN THE PHILIPPINES.
}

Francisco P. Panopio and Consorcia S. Tan.

Bitin Integrated National High School, Laguna State Polytechnic University.

\section{Manuscript Info}

Manuscript History

Received: 24 February 2019

Final Accepted: 26 March 2019

Published: April 2019

Key words:-

bullying, intervention program, barriers, strategies.

\section{Abstract}

This study was conducted to determine the barriers in the implementation of school-based bullying intervention programs and strategies in a certain division in the Philippines. It utilized the descriptive survey research design. Data were gathered through researcher's made questionnaire based on RA 10627, DepEd Child Protection Policy and some research and literature. Weighted mean, standard deviation, frequency distribution, percentage, Pearson Correlation Coefficient, Kendall Tau, Chi-square and Spearman's Correlation Coefficient, and Multiple Regression Posteriori Approach were employed. Hypotheses tested dealt with significant relationships between teacher-related factors and bullying interventions; childprotection policy committee-related factors and barriers to bullying interventions; the teacher-related factors and their responses to schoolbased bullying; CPC-related factors and their responses to school-based bullying; barriers in bullying interventions and teachers' and CPC responses to school-based bullying; the hypothesis on barriers singly or in combination significantly affect the implementation of schoolbased bullying intervention programs and strategies. Home visitation and student's orientation were the main programs in bullying intervention. Providing teachers with effective classroom management training and school administrator/guidance counselors inform lateenrolling students about the school's bullying policy were the main intervention strategies. Age as a teacher-based barrier is found highly significant. Civil status, school-based barriers, teacher-based barriers and student based barriers are found highly significant. As to length of service, teacher-based barriers and school-based barriers are found highly significant and student-based barriers is found significant. As to educational attainment, only school-based barriers is found significant. Age, Constructive-Direct responses and Punitive-Direct response were found to have highly significant relationship. Civil status, ConstructiveDirect responses and Punitive-Direct response were found to have highly significant relationship. As to length of service, ConstructiveDirect responses were found to have highly significant relationship and Punitive-Direct responses were found to have significant relationship. CPC-related factors were found to have no significant relationship to responses to school-based bullying. As to student barriers, all responses 
were found to have highly significant relationship. As to teacher-based barriers and school-based barriers, Punitive-Direct responses is found significant. As to Community-based barriers, all responses were found to have highly significant relationship. As to student barriers, Constructive-Direct and Constructive-Indirect responses were found to have highly significant relationship. As to teacher-based barriers, Punitive-Direct responses were found to have highly significant relationship. As to school-based barriers, Constructive-Direct responses, Punitive-Direct responses-Punitive-Indirect responses have highly significant relationship and Constructive-Indirect responses have significant relationship. As to Community-based barriers, all responses have highly significant relationship. School-based barriers and community-based barriers have found significant effect on bullying intervention programs and strategies. Community-based barriers significantly affect bullying intervention programs and strategies. As to CPC-respondents, in combination, student-based barriers have highly significant effect on bullying intervention programs. Teacher-based barriers significant effect on both bullying intervention programs and strategies. School-based barriers have significant effect on bullying intervention programs and highly significant effect to bullying intervention strategies. Singly, student-based barriers were found to have significant effect on bullying intervention programs. Teacherbased barriers have significant effect on bullying intervention strategies. School-based barriers have highly significant effect on bullying intervention strategies.

Copy Right, IJAR, 2019,. All rights reserved.

\section{Introduction:-}

School bullying has been around for as long as anyone can remember, featured in Wester literature for over 150 years. Today, bullying permeates popular culture in the form of reality TV and violent video games, and in our freemarket, capitalist society (Hymel and Swearer, 2015). In contrast, empirical research on bullying is a relatively recent focus, the earliest studies emerging in the 1970s in Scandinavia. In North America, public concern about school bullying increased dramatically in the late 1990s, owing in large part to the tragic deaths of youth by suicide or murder, especially in the 1997 murder of Rina Virk (Godfrey, 2005) and the Columbine massacre in 1998 (Cullen, 2009). Since then, bullying has received unprecedented attention in the media and in academia, both nationally and internationally (e.g. Jimerson, Swearer, \& Espelage, 2010; Swearer, Espelage, Vaillancourt, \& Hymel, 2010), and remains a significant concern among parents and educators.

Following the pioneering work of Olweus (1978, 1999, 2001), bullying has been defined as a subcategory of interpersonal aggression characterized by intentionality, repetition, and an imbalance of power, with abuse of power being primary distinction between bullying and other forms of aggression (Hymel and Swearer, 2015). Scholars generally endorse these characteristics, as does the U.S. Centers for Disease Control (Gladden, et al, 2014), the American Psychological Association (VandenBos, 2007), and the National Association of School Psychologists (2012). The goal of bullying is to take control over the other person through physical force, verbal teasing, and exclusion from peers, and can also occur in a virtual setting through social networking via and e-mails. Regardless of the form it takes or the medium is uses, the behavior of an individual is considered as bullying if it is intended to hurt another.

Local and international studies have affirmed the alarming situation of bullying and school violence involving Filipino children. The intensity of violence has reached a disturbing rate that has pushed policy-makers to formulate bullying prevention schemes. Despite organized attempts to make schools a safe environment, this dilemma poses critical risks that call for aggressive and determined actions to fight violence in schools.

A 2008 study of Britain-based Plan International showed that one in two school children in the Philippines are bullied or suffer from other forms of abuse inflicted by peers or teachers. Most incidents go unreported due to fear of 
retribution. Plan International said school-related violence against children and the youth has always been detrimental to the realization of the children's full potential (Flores and Sy, The Philippine Star, 2013). In a study conducted by PWU-CWC-UNICEF for Plan Philippines in 2009 "Towards A Child - Friendly Education Environment". Found out that almost 5 out of 10 high school students experience physical violence (such as pinching and hitting) committed by teachers; 7 out of 10 in higher grade levels have complained of verbal abuse by their teachers; $42.88 \%$ of high school students surveyed indicated they have experienced verbal sexual violence in school and $17.60 \%$ of high school students have experienced inappropriate touching; $78.36 \%$ in high school surveyed in urban areas have suffered verbal abuse from their peers; $37.57 \%$ in high school surveyed in rural areas have experienced physical abuse or violence committed by their peers; $43.71 \%$ in high school in urban areas surveyed have experienced verbal sexual abuse committed by their peers and $17.71 \%$ of high school students experienced inappropriate touching committed by their peers.

Bullying in schools has become a widespread problem that can have life-long negative consequences for both the bully and the victim. Because of the long lasting effect it has on those involved, bullying is a hot topic and a definite area of concern for both parents and educators alike. With the enactment of Republic Act 10627 or the "AntiBullying Act of 2013", it required all elementary and secondary schools to adopt policies to prevent and address bullying in their institutions. This law compliments the Department of Education (DepEd)'s existing Child Protection Policy.DepEd Order No. 40, s. 2012, entitled "DepEd Child Protection Policy" mandates concerned individuals the policy and guidelines on the protection of school-children abuse, violence, exploitation, discrimination, bullying and other forms of abuse. The issuance of this policy aims to safeguard the welfare of school children from all forms of violence.

The DepEd's mission that "student learn in a child-friendly, gender-sensitive, safe and motivating environment" ensures that all schools in the country public and private will make the necessary actions to make school climate conducive to learning and administrators and staff as steward of the institution ensure an enabling and supportive environment for effective learning to happen is mandated by our 1987 Constitution; (Article XV, Section 3, Subsections 3 and 4) "The State shall defend the right of children to assistance, including proper care and nutrition, and special protection from all forms of neglect, abuse, cruelty, exploitation, and other conditions prejudicial to their development."

Acts against bullying is also supported by Article 218 of the Family Code of the Philippines which refers to the obligation of school administrators, teachers, academic and non-academic and other personnel. "School staff members play a central in this coalition, from working directly with children who have been exposed to violence, to reaching out to parents and intersecting with law enforcement personnel."

With this comes one of the main thrusts of the Philippines' Education Department in partnership with all involved stakeholders: an assurance that schools be conducive for the learning of children. With the reiteration of the department's stand on bullying and acts of violence, student protection is considered to be a vital element for the students' well-being.

Bullying in schools concerns parents, teachers, school administrators, guidance counselors in most Philippine schools (Ouano, et al, 2013). Bullying refers to any sever, or repeated use by one or more students of a written, verbal or electronic expression, or a physical act or gesture, or any combination thereof, directed at another student that has the effect of actually causing or placing the latter in reasonable fear of physical or emotional harm or damage to his property; crating a hostile environment at school; or materially and substantially disrupting the education process or the orderly operation of a school (IRR, RA 10627 December 13, 2013).

Examining the barriers that inhibit intervention, as well as potential relationships between perceived obstacles and anti-bullying strategies, may provide a clearer understanding of ability and willingness to respond to these harmful behaviors. Perhaps more than any other school safety problem, bullying affects students' sense of security. From the above definitions, some issues are brought to mind that deal with the impact of bullying, how these actions can be mediated or intervened if not fully terminated. The researcher adheres to the belief that the best quality of education schools can offer should include a sound school environment free from threats to their young lives.

Furthermore, the result of this study will serve as a benchmark for the improvement in the implementation of Child Protection Policy and provide DepEd with information about bullying in schools, its extent and its causes, and 
enables the administration to develop policies to steer schools away from common remedies that have proved ineffective elsewhere, and to develop ones that will work.

\section{Methodology:-}

The researcher utilized the descriptive method of the research. This method of research is used to obtain information concerning current status of the phenomena to describe "what exist" with respect to variables or condition in a situation (Key, 2008). The method involved range from the survey which describe the status quo, the correlation study investigates the relationship between variable which is applicable to this study. The descriptive method provides an accurate account of a subject at the time of research.

\section{Respondents of the Study}

The researcher specifically targeted teachers and members of the School's Child Protection Committee. The School's existing Child Protection Committee (CPC) was designated as the School's Anti-Bullying Committee as required under DepEd Order No. 40, series of 2012. The Committee was composed of the Principal - Chairperson, Guidance Counselor - Vice Chairperson, Representative of the Teacher, Representative of the Parents, Representative of the students and Representative of the Community as designed by the Punong Barangay, preferably a member of the Barangay Council for the Protection of Children (BCPC).

\section{Research Instrument}

The researcher used a researcher made survey questionnaire that determines the barriers in the implementation of school - based bullying intervention programs and strategies in the Division of Laguna. It is in a form of a checklist and comprised of four parts. Part I tackles about the respondents' related factors which covers the respondent's age in years, gender, civil status, length of service and highest educational attainment. Part II comprises the barriers in the implementation of school-based bullying intervention programs and strategies, particularly student-based barriers, teacher-based barriers, school-based barriers, and community-based barriers. Part III comprises of the respondent's responses to school-based bullying. Part IV covers the effectiveness of the implementation of schoolbased bullying programs and strategies.

\section{Data Gathering Procedure}

Permission was sought from the School's Division Superintendent and Principals, regarding the conduct of the study. A formal consultation and assistance from the guidance counselors were made for the information needed. Questionnaires were distributed to the members of CPC, and Teacher-respondents. Retrieval of the questionnaires followed. And finally, information and data reflected in the questionnaires were categorized, tabulated, analyzed and interpreted.

\section{Statistical Treatment}

The researcher employed frequency distribution, percentage, mean and standard deviation to describe the respondents and their responses to the questions. Pearson Product-Moment Correlation Coefficient and Kendall Tau (P-value); Chi-Square and Spearman's Rank Correlation Coefficient were employed in measuring relationship between the variables. Multiple Regression Analysis and Posteriori Approach were used to test whether or not the barriers singly or in combination significantly influence the implementation of school-based intervention program.

\section{Results And Discussion:-}

Table 1 presents the distribution of forms of bullying in terms of occurrences as assessed by the teacherrespondents. The result indicate that verbal bullying 580 or $40.3 \%$ rank first or most common occurrences that the teacher-respondents have perceived thus, the teacher-respondents are deeply concerned and familiar with this form of bullying and consider it as a serious problem with serious effect. On the other hand, physical bullying 424 or 29.5 $\%$ rank second, followed by social bullying 491 or $34.1 \%$ rank third, cyber bullying 402 or $27.9 \%$ rank fourth and sexual bullying 590 or $41 \%$ rank fifth, the teacher-respondents considered least common form of bullying and slightly concerned. This is supported by the study conducted by Ouano, Buot Dela Rosa and Conway (2013) which stated that bullying experiences of Filipino students in public and private school includes 3 forms namely physical, verbal-relational, and cyber-bullying. 
Table 1:-Forms of Bullying in terms of occurrences as assessed and rankedby Teacher-Respondents

\begin{tabular}{|c|c|c|c|c|c|c|c|c|c|c|}
\hline \multirow[t]{2}{*}{ Forms of Bullying } & \multicolumn{2}{|c|}{ Rank 1} & \multicolumn{2}{|c|}{ Rank 2} & \multicolumn{2}{|c|}{ Rank 3} & \multicolumn{2}{|c|}{ Rank4 } & \multicolumn{2}{|c|}{ Rank5 } \\
\hline & f & $\%$ & $\mathbf{f}$ & $\%$ & f & $\%$ & f & $\%$ & f & $\%$ \\
\hline Cyber Bullying & 283 & 19.7 & 232 & 16.1 & 250 & 17.4 & 402 & 27.9 & 272 & 18.9 \\
\hline Social Bullying & 123 & 8.5 & 403 & 28.0 & 491 & 34.1 & 307 & 21.3 & 115 & 8.0 \\
\hline Verbal Bullying & 580 & 40.3 & 237 & 16.5 & 247 & 17.2 & 160 & 11.1 & 215 & 14.9 \\
\hline Sexual Bullying & 231 & 16.1 & 149 & 10.4 & 176 & 12.2 & 292 & 20.3 & 590 & 41.0 \\
\hline Physical Bullying & 218 & 15.1 & 424 & 29.5 & 282 & 19.6 & 272 & 18.9 & 243 & 16.9 \\
\hline
\end{tabular}

The result of this study is supported by the study conducted by Vaillancourt, Trinh, et al. (2010) found that $31 \%$ of Grade 4 through 12 students reported being physically bullied by peers and $12 \%$ reported being cyberbullied, whereas $51 \%$ and $37 \%$ reported being verbally and socially bullied, respectively. Students are often aware of rules prohibiting physical harm to others, but verbal and social bullying are more difficult to identify. Adults rely on youth to report bullying, especially in its more covert forms, and classrooms in which students are more willing to report bullying are characterized by less, not more, victimization (Cortes \& Kochenderfer-Ladd, 2014).

The obtained data from table 2 presents the distribution of forms of bullying in terms of occurrences as assessed by the teacher- respondents. The result indicate that cyber- bullying 91 or $34.6 \%$ rank first or most common occurrences that the CPC-respondents have perceived, thus the CPC-respondents are deeply concerned and familiar with this form of bullying and consider it as a serious problem with serious effect. On the other hand physical bullying 93 or $35.4 \%$ rank second, followed by social bullying 107 or $40.7 \%$ rank third, verbal bullying 71 or 27.0 $\%$ rank fourth and sexual bullying 115 or $43.7 \%$ rank fifth, the CPC-respondents considered least common form of bullying and slightly concerned.

Table 2:-Forms of Bullying in terms of occurrences as perceived and ranked by CPC-Respondents

\begin{tabular}{|l|l|l|l|l|l|l|l|l|l|l|}
\hline \multirow{2}{*}{ Forms of Bullying } & \multicolumn{2}{|l|}{ Rank 1 } & \multicolumn{2}{l|}{ Rank 2 } & \multicolumn{2}{l|}{ Rank 3 } & \multicolumn{2}{l|}{ Rank4 } & \multicolumn{2}{l|}{ Rank5 } \\
\cline { 2 - 12 } & f & \% & f & \% & f & \% & f & \% & f & \% \\
\hline Cyber Bullying & 91 & 34.6 & 72 & 27.4 & 22 & 8.4 & 35 & 13.3 & 43 & 16.3 \\
\hline Social Bullying & 32 & 12.2 & 50 & 19.0 & 107 & 40.7 & 55 & 20.9 & 19 & 7.2 \\
\hline Verbal Bullying & 49 & 18.6 & 30 & 11.4 & 61 & 23.2 & 71 & 27.0 & 52 & 19.8 \\
\hline Sexual Bullying & 49 & 18.6 & 18 & 6.8 & 47 & 17.9 & 34 & 12.9 & 115 & 43.7 \\
\hline Physical Bullying & 42 & 16.0 & 93 & 35.4 & 26 & 9.9 & 68 & 25.9 & 34 & 12.9 \\
\hline
\end{tabular}

Previous studies reported similar result where a substantial amount of cyber bullying experience among students at some point in their lives (Beran and $\mathrm{Li}, 2007$ ). Considering Filipino high school students use cyberspace to interact with other individuals (Gultiano, King, Orbeta and Gordoncillo, 2010) it is not surprising to find out that many of these students are victims of bullying. In a study conducted by Ouano, et.al. in 2013, the dimension in physical bullying also emerged from exploratory investigation of the factor structure of bullying and was confirmed to be present in both public and private high school students. The presence of the physical form of bullying is still evident. However, physical bullying showed consistently low mean score. Two possible explanation for this, one, this type of aggression among student in high school is less obvious according to the developmental perspective of physical aggression.

Juvonen and Witkow (2005) explain this case as a result of widening of social understanding as student grow. Another reason for this is that high school students may take physical bullying as a more obvious form of bullying that makes the aggressive attack more observable by other people, teachers and school authorities, and more easily subjected to investigation with reference to existing school policies.

The result of this study is also similar to Bradshaw, Waasdorp, and O'Brennan study in 2010 which mentioned that teachers perceived bullying to be a problem in their school; they witnessed bullying frequently and students reported it to them in large numbers. Although approximately $43 \%$ of those surveyed perceived bullying to be a moderate or major problem at their school, over half of the respondents surveyed $(62 \%)$ indicated that they had witnessed bullying two or more times in the last month and $41 \%$ indicated that they had witnessed bullying once a week or more. Teachers reported witnessing significantly more students being bullied at their school in the past month. 
Teachers also viewed bullying as a significantly greater problem at their school. Bullying is pervasive in all grades and all schools nationwide. It is observed across gender, race, ethnicity, and socioeconomic status. The percentages of students involved in bullying vary widely according to the definition of bullying that is used; however, in a study conducted by one nationally representative survey found that approximately $28 \%$ of students ages 12 to 18 reported being bullied at school during the school year as cited by Robers, Zhang, Truman, \& Snyder, 2012. Other studies have found comparably high percentages of students who admit bullying their peers (Wang, Iannotti, \& Nansel, 2009). When the impact of bullying on bystanders is considered along with the impact on victims and aggressors, it is likely that bullying affects most students at some time during a typical school year.

The gathered data on Table 3 present the extent of seriousness of forms of bullying problems in schools as assessed by teacher-respondents. The result shows that 672 or $46.7 \%$ classified bullying problems with moderate seriousness, 498 or $34.6 \%$ classified bullying problem with significant seriousness, 227 or $15.8 \%$ classified bullying problems with extremely significant seriousness and 42 or $2.9 \%$ classified bullying problems as not at all.

Table 3 also reveals the extent of seriousness of forms of bullying problems in schools as assessed by CPCrespondents. The result shows that 163 or $62.0 \%$ classified bullying problems with moderate seriousness, 52 or 19.8 $\%$ classified bullying problem with significant seriousness, 36 or $13.7 \%$ classified bullying problems with extremely significant seriousness and 12 or 4.6 percent classified bullying problems as not at all. Both teacherrespondents and CPC viewed bullying in schools the same in terms of seriousness.

Table 3:-Extent of Seriousness of Bullying Problems of Schools as Assessed by Teacher and CPC-Respondents

\begin{tabular}{|l|l|l|l|l|}
\hline $\begin{array}{l}\text { Extent of seriousness of } \\
\text { bullying problem in } \\
\text { schools }\end{array}$ & \multicolumn{2}{l|}{ Teacher-Respondents } & CPC-Respondents \\
\hline & f & \% & f & \% \\
\hline Not at all & 42 & 2.9 & 12 & 4.6 \\
\hline Moderate & 672 & 46.7 & 163 & 62.0 \\
\hline Significant & 498 & 34.6 & 52 & 19.8 \\
\hline Extremely Significant & 227 & 15.8 & 36 & 13.7 \\
\hline Total & 1439 & 100.0 & 263 & 100.0 \\
\hline
\end{tabular}

Lazarus and Pfohl (2010) stated in their study that because of teachers unable to be everywhere in school, and because bullying occurs underneath their radar, teachers may grossly underestimate the amount of bullying that goes on their school. This is especially true for cyber-bullying and verbal-relational bullying. Further, reluctant to intervene in bullying and student report that teachers are ineffective in both preventing and intervening with bullying. Given the long-term consequences for both bully and target, it is critical that teacher recognize and effectively address bullying behavior in the classroom.

Although prior studies have indicated that some school personnel perceived no barriers to implementation of bullying prevention and intervention efforts (Hendershot et al., 2006), all participants in the current study reported experiencing barriers. This unique finding has several implications. First, these results highlight the importance of examining barriers based on teachers' personal experiences and perceptions of bullying. If teachers' perspectives are not explored, we may not be gaining an accurate understanding of the obstacles teachers face when responding to bullying. Second, teachers in this study reported that bullying occurred frequently in their schools, with many participants reporting multiple incidents in a single week. Further, participants perceived bullying to be moderately to significantly serious.

Prior studies have indicated that teachers' who perceived bullying to be a serious occurrence were more likely to respond to these behaviors (Ellis \& Shute, 2007). Since teachers in this study perceived bullying to be both prevalent and serious, teacher-respondents may have been more likely to respond to bullying, thus demonstrated an increased awareness of the barriers that inhibit these interventions.

Table 4 presents the distribution of instances of bullying witnessed by teacher-respondents. The result shows that 504 or $35 \%$ of the teacher-respondents have witnessed bullying incident monthly, 467 or $32.5 \%$ of teacherrespondents witnessed bullying incident weekly, 339 or $23 \%$ witnessed bullying incident daily and 129 or $9 \%$ have never witnessed bullying incident. 
Table 4:-Instances of Bullying of School as witness by Teacher-Respondents and CPC- Respondents

\begin{tabular}{|c|c|c|c|c|}
\hline \multirow{2}{*}{$\begin{array}{l}\text { Instances of bullying in } \\
\text { school }\end{array}$} & \multicolumn{2}{|c|}{ Teacher-Respondents } & \multicolumn{2}{|c|}{ CPC-Respondents } \\
\hline & $\mathbf{f}$ & $\%$ & $\mathbf{f}$ & $\%$ \\
\hline Never & 129 & 9.0 & 16 & 6.1 \\
\hline Daily & 339 & 23.6 & 28 & 10.6 \\
\hline Weekly & 467 & 32.5 & 59 & 22.4 \\
\hline Monthly & 504 & 35 & 160 & 60.8 \\
\hline Total & 1439 & 100.0 & 263 & 100.0 \\
\hline
\end{tabular}

Table 4 further reveals the distribution of instances of bullying witness by CPC-respondents. The result shows that 160 or $60.8 \%$ of the teacher-respondents have witnessed bullying incident monthly, 59 or $22.4 \%$ of teacherrespondents witnessed bullying incident weekly, 28 or $10.6 \%$ witnessed bullying incident daily and 16 or $6.1 \%$ have never witnessed bullying incident. It further confirms that bullying as a prevalent problem is recurring or repetitive in nature (Tandang, 2015). In a study conducted by the American Academy of Pediatrics in 2009, one of the characteristics of bullying is that "it is repeatedly done on the same person to intimidate, harass, or physically harm a victim who is perceived as unable to depend himself or herself, and there is an imbalance of power in term of size, strength and social status.

Table 5 reflects the teacher-respondents' assessment on student-based barriers in bullying interventions. The result shows that students intentionally bully outside of teacher's view with a mean of 2.97 and a standard deviation of 0.85 , often, with moderate extent and frequently happening with moderate effect is considered by teacherrespondent as the main student-based barriers followed by bullying denied when confronted with a mean of 2.83 and a standard deviation of 0.86 , often, with moderate extent, frequently happening with moderate effect, individual student factor like shyness and fear of retaliation with a mean of 2.80 and a standard deviation of 0.77 , often, with moderate extent, frequently happening with moderate effect, lack of student knowledge or skills to differentiate bullying and aggression with a mean of 2.62 and a standard deviation of 0.79 , often, with moderate extent and frequently happening with moderate effect, not informing teachers with a mean of 2.54 and a standard deviation of 0.88 , often, with moderate extent and frequently happening with moderate effect. However, students encourage bullying with a mean of 2.24 and a standard deviation of 0.90 , rarely with small extent and rarely happening with minor effect is assessed by teacher-respondents as least student-based barrier. An overall mean of 2.666 and standard deviation of 0.580 , often, with moderate extent, frequently happening with moderate effect is assessed by teacher-respondents on student-based barriers.

Table 5:-Teachers-Respondents Assessment on Student-Based Barriers to Bullying Interventions

\begin{tabular}{|c|c|c|c|c|c|c|}
\hline Statement & SD & Mean & Rank & $\begin{array}{l}\text { Qualitative } \\
\text { Interpretation }\end{array}$ & Scale & $\begin{array}{l}\text { Descriptive } \\
\text { Interpretation }\end{array}$ \\
\hline $\begin{array}{l}\text { 1. Not informing } \\
\text { teachers }\end{array}$ & 0.88 & 2.54 & 5 & Moderate Extent & Often & $\begin{array}{l}\text { Frequently happening } \\
\text { with moderate effect }\end{array}$ \\
\hline $\begin{array}{l}\text { 2. Lack of student } \\
\text { knowledge or skills to } \\
\text { differentiate bullying } \\
\text { and aggression }\end{array}$ & 0.79 & 2.62 & 4 & Moderate Extent & Often & $\begin{array}{l}\text { Frequently happening } \\
\text { with moderate effect }\end{array}$ \\
\hline $\begin{array}{l}\text { 3. Bullying denied } \\
\text { when confronted }\end{array}$ & 0.86 & 2.83 & 2 & Moderate Extent & Often & $\begin{array}{l}\text { Frequently happening } \\
\text { with moderate effect }\end{array}$ \\
\hline 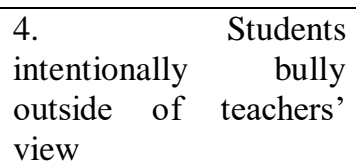 & 0.85 & 2.97 & 1 & Moderate Extent & Often & $\begin{array}{l}\text { Frequently happening } \\
\text { with moderate effect }\end{array}$ \\
\hline $\begin{array}{l}\text { 5. Students encourage } \\
\text { bullying }\end{array}$ & 0.90 & 2.24 & 6 & Small Extent & Rarely & $\begin{array}{l}\text { Rarely happening with } \\
\text { minor effect }\end{array}$ \\
\hline $\begin{array}{l}\text { 6. Individual student } \\
\text { factors }\end{array}$ & 0.77 & 2.80 & 3 & Moderate Extent & Often & $\begin{array}{l}\text { Frequently happening } \\
\text { with moderate effect }\end{array}$ \\
\hline Over all & 0.580 & 2.666 & & Moderate extent & Often & $\begin{array}{l}\text { Frequently happening } \\
\text { with moderate effect }\end{array}$ \\
\hline
\end{tabular}


Legend:3.50 - 4.00 - Always, Great Extent, Very frequently, happening with major effect; 2.50 - 3.49 - Often, Moderate Extent, Frequently happening with moderate effect; 1.50 - 2.49 - Rarely, Small Extent, Rarely happening with minor effect; $1.00-1.49$ - Never, Not a concern, Not happening with no effect at all Yet, in a study conducted by Oliver and Candappa in 2007, students are reluctant to report bullying, given legitimate fears of negative repercussions or ineffective adult responses. Positive relationships between teachers and students may enhance the likelihood of student reporting, but this relationship is not always observed (Cortes \& Kochenderfer-Ladd, 2014), and with age, students' willingness to report bullying declines steadily (Aceves, Hinshaw, Mendoza-Denton, \& Page-Gould, 2010; Kochenderfer-Ladd \& Pelletier, 2008: Trach, Hymel, Waterhouse, \& Neale, 2010). In a study of Cortes and Kochenderfer- Ladd (2014) found that students were more likely to report bullying when they believed that teachers would respond actively by involving parents and/or separating the students involved, and less likely to report when they expected teachers to punish the perpetrator, presumably for fear of retaliation or ridicule.

Table 6 reflects the teacher-respondents' assessment on teacher-based barriers in bullying interventions. The result shows that lack of time to address bullying with a mean of 2.23 and a standard deviation of 0.81 , rarely, with small extent, rarely happening with minor effect, is considered by teacher-respondent as the main student-based barriers followed by lack of knowledge and skills to effectively intervene with a mean of 2.21 and a standard deviation of 0.87 , rarely, with small extent, rarely happening with minor effect, lack relationship to students with a mean of 2.20 and a standard deviation of 0.80 , rarely, with small extent, rarely happening with minor effect, difficulty to identify bullying with a mean of 2.08 and a standard deviation of 0.88 , rarely, with small extent, rarely happening with minor effect. An overall mean of 2.180 and standard deviation of 0.719 , rarely, with small extent, rarely happening with minor effect, is assessed by teacher-respondents on teacher-based barriers.

The result is supported by Marshalls study in 2012 described the presence of numerous barriers that challenged their ability to consistently and effectively respond to bullying. Results indicated that these obstacles occurred on multiple levels and included Student-, Teacher-, School- and Sociocultural-Based Barriers.

Table 6:-Teacher-Respondents Assessment on Teacher-Based Barriers to Bullying Interventions

\begin{tabular}{|l|l|l|l|l|l|l|}
\hline Statement & SD & Mean & Rank & $\begin{array}{l}\text { Qualitative } \\
\text { Interpretation }\end{array}$ & Scale & $\begin{array}{l}\text { Descriptive } \\
\text { Interpretation }\end{array}$ \\
\hline $\begin{array}{l}\text { 1. Lack of knowledge or } \\
\text { skills to effectively } \\
\text { intervene }\end{array}$ & 0.87 & 2.21 & 2 & Small Extent & Rarely & $\begin{array}{l}\text { Rarely happening } \\
\text { with minor effect }\end{array}$ \\
\hline $\begin{array}{l}\text { 2. Difficult to identify } \\
\text { bullying }\end{array}$ & 0.88 & 2.08 & 4 & Small Extent & Rarely & $\begin{array}{l}\text { Rarely happening } \\
\text { with minor effect }\end{array}$ \\
\hline $\begin{array}{l}\text { 3. Lack of relationship } \\
\text { with students }\end{array}$ & 0.80 & 2.20 & 3 & Small Extent & Rarely & $\begin{array}{l}\text { Rarely happening } \\
\text { with minor effect }\end{array}$ \\
\hline $\begin{array}{l}\text { 4. Lack of time to } \\
\text { consistently address } \\
\text { bullying }\end{array}$ & 0.81 & 2.23 & 1 & Small Extent & Rarely & $\begin{array}{l}\text { Rarely happening } \\
\text { with minor effect }\end{array}$ \\
\hline Over all & 0.719 & 2.180 & & Small Extent & Rarely & $\begin{array}{l}\text { Rarely happening } \\
\text { with minor effect }\end{array}$ \\
\hline
\end{tabular}

Legend: 3.50 - 4.00 - Always, Great Extent, Very frequently, happening with major effect; 2.50 - 3.49 - Often, Moderate Extent, Frequently happening with moderate effect; 1.50 - 2.49 - Rarely, Small Extent, Rarely happening with minor effect; 1.00 - 1.49 - Never, Not a concern, Not happening with no effect at all For example, barriers to effective intervention were identified based on participants own perceived inadequacies (e.g., lack of knowledge or skills, difficulty identifying bullying), school-related concerns (e.g., ineffective school policies, lack of administrative support, inadequate school-based resources, other educators"e lack of time and/or skills), sociocultural influences (e.g., community resources and perceptions, parental responses) and student-related factors (e.g., personal factors, not informing teachers).

Table 7 presents the teacher-respondents assessment on school-based barriers to bullying interventions. The result shows that school climate factors with a mean of 2.42 and a standard deviation of 0.81 , rarely, small extent, rarely happening with minor effect, is considered by teacher-respondents as the main school-based barrier followed by differing perceptions among school staff with a mean of 2.38 and a standard deviation of 0.77 , rarely, small extent, 
rarely happening with minor effect, ineffective discipline policies and / or consequences with a mean of 2.36 and a standard deviation of 0.89 , rarely, small extent, rarely happening with minor effect, lack of resources and / or administrative support with a mean of 2.24 and a standard deviation of 0.85 , rarely, small extent, rarely happening with minor effect, lack of time for other school staff to consistently address bullying with a mean of 2.10 and a standard deviation of 0.80 , rarely, small extent, rarely happening with minor effect, other staffs' lack of knowledge and skills to effectively intervene with a mean of 2.19 and a standard deviation of 0.80 , rarely, small extent, rarely happening with minor effect, ineffective supervision of students with a mean of 2.11 and a standard deviation of 0.84 , rarely, small extent, rarely happening with minor effect, and lastly, bullying between school staff and students with a mean of 1.98 and a standard deviation of 0.85 , rarely, small extent, rarely happening with minor effect. An overall mean of 2.233 and standard deviation of 0.652 , rarely, with small extent, rarely happening with minor effect, is assessed by teacher-respondents on school-based barriers.

Table 7:-Teacher-Respondents Assessment on School-Based Barriers to Bullying Interventions

\begin{tabular}{|l|l|l|l|l|l|l|}
\hline Statement SD & Mean & Rank & $\begin{array}{l}\text { Qualitative } \\
\text { Interpretation }\end{array}$ & Scale & $\begin{array}{l}\text { Descriptive } \\
\text { Interpretation }\end{array}$ \\
\hline $\begin{array}{l}\text { 1. Ineffective discipline } \\
\text { policies and / or } \\
\text { consequences }\end{array}$ & 0.89 & 2.36 & 3 & Small Extent & Rarely & $\begin{array}{l}\text { Rarely happening } \\
\text { with minor effect }\end{array}$ \\
\hline $\begin{array}{l}\text { 2. Differing perceptions } \\
\text { among school staff }\end{array}$ & 0.77 & 2.38 & 2 & Small Extent & Rarely & $\begin{array}{l}\text { Rarely happening } \\
\text { with minor effect }\end{array}$ \\
\hline $\begin{array}{l}\text { 3. School climate factors } \\
\text { 4. Bullying between } \\
\text { school staff and students }\end{array}$ & 0.81 & 2.42 & 1 & Small Extent & Rarely & $\begin{array}{l}\text { Rarely happening } \\
\text { with minor effect }\end{array}$ \\
\hline $\begin{array}{l}\text { 5. Ineffective supervision } \\
\text { of students }\end{array}$ & 0.84 & 2.11 & 7 & Small Extent & Rarely & $\begin{array}{l}\text { Rarely happening } \\
\text { with minor effect } \\
\text { with minor effect }\end{array}$ \\
\hline $\begin{array}{l}\text { 6. Lack of time for other } \\
\text { school staff to } \\
\text { consistently address } \\
\text { bullying }\end{array}$ & 0.80 & 2.19 & 5 & Small Extent & Rarely & $\begin{array}{l}\text { Rarely happening } \\
\text { with minor effect }\end{array}$ \\
\hline $\begin{array}{l}\text { 7. Other staffs lack of } \\
\text { knowledge or skills to } \\
\text { effectively intervene }\end{array}$ & 0.80 & 2.18 & 6 & Small Extent & Rarely & $\begin{array}{l}\text { Rarely happening } \\
\text { with minor effect }\end{array}$ \\
\hline $\begin{array}{l}\text { 8. Lack of resources and / } \\
\text { or administrative support }\end{array}$ & 0.85 & 2.24 & 4 & Small Extent & Rarely & $\begin{array}{l}\text { Rarely happening } \\
\text { with minor effect }\end{array}$ \\
\hline $\begin{array}{l}\text { Over all happening } \\
\text { Rarely harely } \\
\text { with minor effect }\end{array}$ \\
\hline
\end{tabular}

Legend: 3.50 - 4.00 - Always, Great Extent, Very frequently, happening with major effect; 2.50 - 3.49 - Often, Moderate Extent, Frequently happening with moderate effect; 1.50 - 2.49 - Rarely, Small Extent, Rarely happening with minor effect; $1.00-1.49$ - Never, Not a concern, Not happening with no effect at all Moreover, many of the self-reported barriers identified by teachers in this study were consistent with researcher-generated lists of barriers used in prior research (Hendershot, Dake, Price, \& Lartey, 2006). For instance, Hendershot and colleagues (2006) asked 404 elementary school nurses in the U.S. to indicate whether or not they experienced specific barriers (based on a presented list) to bullying intervention. Fifty-two percent of school nurses reported that their responses to bullying were hindered because these behaviors often occurred in places where they were not supervising (i.e., outside of their view). A little more than one-quarter of participants indicated they did not have enough time (28\%) and felt unprepared (27\%) to address these behaviors.Further, $15 \%$ reported inadequate administrative support, while $11 \%$ were unsure of the signs of bullying (i.e., difficult to identify bullying; Hendershot et al., 2006).

On the other hand, several barriers included on the survey and endorsed by school nurses (Hendershot et al., 2006) were not reported by teachers in the current study. These barriers indicated that other school personnel were more qualified to intervene (45\%), it was not their job to address bullying $(21 \%)$, there were no barriers (15\%), no bullying prevention efforts existed (9\%), and the school board would not have supported their effort (4\%; Hendershot et al., 2006). 
Table 8 reflects the teacher-respondents' assessment on community-based barriers in bullying interventions. Moreover, many of the self-reported barriers identified by teachers in this study were consistent with researchergenerated lists of barriers used in prior research (Hendershot, Dake, Price, \& Lartey, 2006). For instance, Hendershot and colleagues (2006) asked 404 elementary school nurses in the U.S. to indicate whether or not they experienced specific barriers (based on a presented list) to bullying intervention. Fifty-two percent of school nurses reported that their responses to bullying were hindered because these behaviors often occurred in places where they were not supervising (i.e., outside of their view). A little more than one-quarter of participants indicated they did not have enough time $(28 \%)$ and felt unprepared $(27 \%)$ to address these behaviors.

The result shows that parents' reaction to bullying, prevalence of bullying occurring outside the school and differing behavioral expectation all have a mean of 2.68 with a standard deviation of $0.77,0.74$, and 0.71 respectively, often, with moderate extent, frequently happening

Table 8:-Teacher-Respondents Assessment on Community-Based Barriers to Bullying Interventions

\begin{tabular}{|l|l|l|l|l|l|}
\hline Statement & SD & Mean & $\begin{array}{l}\text { Qualitative } \\
\text { Interpretation }\end{array}$ & Scale & $\begin{array}{l}\text { Descriptive } \\
\text { Interpretation }\end{array}$ \\
\hline $\begin{array}{l}\text { 1. Parent's reaction to } \\
\text { bullying }\end{array}$ & 0.77 & 2.68 & Moderate Extent & Often & $\begin{array}{l}\text { Frequently happening } \\
\text { with moderate effect }\end{array}$ \\
\hline $\begin{array}{l}\text { 2. Prevalence of bullying } \\
\text { occurring outside of school }\end{array}$ & 0.74 & 2.68 & Moderate Extent & Often & $\begin{array}{l}\text { Frequently happening } \\
\text { with moderate effect }\end{array}$ \\
\hline $\begin{array}{l}\text { 3. Differing behavioral } \\
\text { expectations }\end{array}$ & 0.71 & 2.68 & Moderate Extent & Often & $\begin{array}{l}\text { Frequently happening } \\
\text { with moderate effect }\end{array}$ \\
\hline $\begin{array}{l}\text { 4. Perception of bullying } \\
\text { among community members. }\end{array}$ & 0.70 & 2.65 & Moderate Extent & Often & $\begin{array}{l}\text { Frequently happening } \\
\text { with moderate effect }\end{array}$ \\
\hline Over all & 0.613 & 2.669 & Moderate Extent & Often & $\begin{array}{l}\text { Frequently happening } \\
\text { with moderate effect }\end{array}$ \\
\hline
\end{tabular}

Legend:3.50 - 4.00 - Always, Great Extent, Very frequently, happening with major effect; 2.50 - 3.49 - Often, Moderate Extent, Frequently happening with moderate effect; 1.50 - 2.49 - Rarely, Small Extent, Rarely happening with minor effect; $1.00-1.49$ - Never, Not a concern, Not happening with no effect at all with moderate effect are considered by teacher-respondents as the main community-based barriers followed by perception of bullying among community members with a mean of 2.75 and a standard deviation of 0.70 , often, with moderate extent and frequently happening with moderate effect. An overall mean of 2.669 and standard deviation of 0.613 , often, with moderate extent and frequently happening with moderate effect, is assessed by teacher-respondents on communitybased barriers.

Findings from the study of Marshalls in 2012 have important implications for both preparing teachers to manage bullying and informing school-based bullying intervention and prevention efforts. Examining and addressing teachers ${ }^{e e}$ perceived barriers may identify explicit ways in which school leaders, policy makers, and researchers can increase the likelihood of consistent and effective implementation of bullying-related responses by teachers. For instance, the barrier reported by most teachers in this study revealed their own lack of skills or knowledge as a hindrance to successful intervention.

Table 9 reflects the CPC-respondents' assessment on student-based barriers in bullying

Table 9:-CPC-Respondents Assessment on Student-Based Barriers to Bullying Interventions

\begin{tabular}{|l|l|l|l|l|l|l|}
\hline Statement & SD & Mean & Rank & $\begin{array}{l}\text { Qualitative } \\
\text { Interpretation }\end{array}$ & Scale & $\begin{array}{l}\text { Descriptive } \\
\text { Interpretation }\end{array}$ \\
\hline $\begin{array}{l}\text { 1. Not informing } \\
\text { teachers }\end{array}$ & 0.77 & 2.10 & 5 & Small Extent & Rarely & $\begin{array}{l}\text { Rarely happening with } \\
\text { minor effect }\end{array}$ \\
\hline $\begin{array}{l}\text { 2. Lack of student } \\
\text { knowledge or skills } \\
\text { to differentiate }\end{array}$ & 0.77 & 2.45 & 4 & Small Extent & Rarely & $\begin{array}{l}\text { Rarely happening with } \\
\text { minor effect }\end{array}$ \\
\hline
\end{tabular}




\begin{tabular}{|l|l|l|l|l|l|l|}
\hline $\begin{array}{l}\text { bullying and } \\
\text { aggression }\end{array}$ & & & & & \\
\hline $\begin{array}{l}\text { 3. Bullying denied } \\
\text { when confronted }\end{array}$ & 0.85 & 2.66 & 1 & Moderate Extent & Often & $\begin{array}{l}\text { Frequently happening } \\
\text { with moderate effect }\end{array}$ \\
\hline $\begin{array}{l}\text { 4. Students } \\
\text { intentionally bully } \\
\text { outside of teachers' } \\
\text { view }\end{array}$ & 0.84 & 2.61 & 2 & Moderate Extent & Often & $\begin{array}{l}\text { Frequently happening } \\
\text { with moderate effect }\end{array}$ \\
\hline $\begin{array}{l}\text { 5. Students } \\
\text { encourage bullying }\end{array}$ & 0.78 & 1.95 & 6 & Small Extent & Rarely & $\begin{array}{l}\text { Rarely happening with } \\
\text { minor effect }\end{array}$ \\
\hline $\begin{array}{l}\text { 6. Individual } \\
\text { student factors }\end{array}$ & 0.79 & 2.51 & 3 & Moderate Extent & Often & $\begin{array}{l}\text { Frequently happening } \\
\text { with moderate effect }\end{array}$ \\
\hline $\begin{array}{l}\text { Over all arely happening with } \\
\text { minor effect }\end{array}$ \\
\hline
\end{tabular}

Legend:3.50 - 4.00 - Always, Great Extent, Very frequently, happening with major effect; 2.50 - 3.49 - Often, Moderate Extent, Frequently happening with moderate effect; 1.50 - 2.49 - Rarely, Small Extent, Rarely happening with minor effect; $1.00-1.49$ - Never, Not a concern, Not happening with no effect at all interventions. The result shows that bullying denied when confronted with a mean of 2.66 and a standard deviation of 0.85 , often, with moderate extent and frequently happening with moderate effect is considered by CPC-respondent as the main student-based barriers followed by students intentionally bully outside teachers view with a mean of 2.61 and a standard deviation of 0.84 , often, with moderate extent and frequently happening with moderate effect, individual student factor like shyness and fear of retaliation with a mean of 2.51 and a standard deviation of 0.79 , often, with moderate extent, frequently happening with moderate effect, lack of student knowledge or skills to differentiate bullying and aggression with a mean of 2.45 and a standard deviation of 0.77 , rarely, with small extent and rarely happening with minor effect, not informing teachers with a mean of 2.10 and a standard deviation of 0.77 , rarely, with small extent and rarely happening with minor effect.

However, students encourage bullying with a mean of 1.95 and a standard deviation of 0.78 , rarely with small extent and rarely happening with minor effect is assessed by teacher-respondents as least student-based barrier. An overall mean of 2.380 and standard deviation of 0.505 , rarely, with small extent, rarely happening with minor effect is assessed by CPC-respondents on student-based barriers.

Table 10 reflects the CPC-respondents' assessment on teacher-based barriers in bullying interventions. The result shows that lack of relationship with students with a mean of 2.32 and a standard deviation of 0.76 , is considered by CPC-respondents as the main teacher-based barriers followed by lack of time to consistently address bullying with a mean of 2.29, and a standard deviation of 0.75 , lack of knowledge or skills to effectively intervene with a mean of 2.28 and a standard deviation of 0.76 , difficult to identify bullying with a mean of 2.19 and standard deviation of 0.78. All teacher-based barriers are assessed by CPC-respondents as rarely, small extent, rarely happening with minor effect. An overall mean of 2.268 and standard deviation of 0.646 , rarely, with small extent, rarely happening with minor effect, is assessed by CPC-respondents on teacher-based barriers.

Table 10:-CPC-Respondents Assessment on Teacher-Based Barriers to Bullying Interventions

\begin{tabular}{|l|l|l|l|l|l|l|}
\hline Statement & SD & Mean & Rank & $\begin{array}{l}\text { Qualitative } \\
\text { Interpretation }\end{array}$ & Scale & $\begin{array}{l}\text { Descriptive } \\
\text { Interpretation }\end{array}$ \\
\hline $\begin{array}{l}\text { 1. Lack of knowledge } \\
\text { or skills to effectively } \\
\text { intervene }\end{array}$ & 0.76 & 2.28 & 3 & Small Extent & Rarely & $\begin{array}{l}\text { Rarely happening } \\
\text { with minor effect }\end{array}$ \\
\hline $\begin{array}{l}\text { 2. Difficult to identify } \\
\text { bullying }\end{array}$ & 0.78 & 2.19 & 4 & Small Extent & Rarely & $\begin{array}{l}\text { Rarely happening } \\
\text { with minor effect }\end{array}$ \\
\hline $\begin{array}{l}\text { 3. Lack of relationship } \\
\text { with students }\end{array}$ & 0.76 & 2.32 & 1 & Small Extent & Rarely & $\begin{array}{l}\text { Rarely happening } \\
\text { with minor effect }\end{array}$ \\
\hline
\end{tabular}




\begin{tabular}{|l|l|l|l|l|l|l|}
\hline $\begin{array}{l}\text { 4. Lack of time to } \\
\text { consistently address } \\
\text { bullying }\end{array}$ & 0.75 & 2.29 & 2 & Small Extent & Rarely & $\begin{array}{l}\text { Rarely happening } \\
\text { with minor effect }\end{array}$ \\
\hline Over all & 0.646 & 2.268 & & Small Extent & Rarely & $\begin{array}{l}\text { Rarely happening } \\
\text { with minor effect }\end{array}$ \\
\hline
\end{tabular}

Legend:3.50 - 4.00 - Always, Great Extent, Very frequently, happening with major effect; 2.50 - 3.49 - Often, Moderate Extent, Frequently happening with moderate effect; 1.50 - 2.49 - Rarely, Small Extent, Rarely happening with minor effect; $1.00-1.49$ - Never, Not a concern, Not happening with no effect at allTable 11 presents the CPCrespondents assessment on school-based barriers to bullying interventions. The result shows that differing perceptions among school staff with a mean of 2.40 and a standard deviation of 0.74 is considered by CPCrespondents as the main school-based barrier followed by lack of resources and / or administrative support with a mean of 2.33 and a standard deviation of 0.83 , ineffective supervision of students with a mean of 2.32 and a standard deviation of 0.81 school climate factor with a mean of 2.19 and a standard deviation of 0.66 , lack of time for other school staff to consistently address bullying with a mean of 2.18 and a standard

Table 11:-CPC-Respondents Assessment on School-Based Barriers to Bullying Interventions

\begin{tabular}{|c|c|c|c|c|c|c|}
\hline Statement & $\mathrm{SD}$ & Mean & Rank & $\begin{array}{l}\text { Qualitative } \\
\text { Interpretation }\end{array}$ & Scale & $\begin{array}{l}\text { Descriptive } \\
\text { Interpretation }\end{array}$ \\
\hline $\begin{array}{l}\text { 1. Ineffective } \\
\text { discipline policies and } \\
\text { / or consequences }\end{array}$ & 0.71 & 2.06 & 8 & Small Extent & Rarely & $\begin{array}{l}\text { Rarely happening } \\
\text { with minor effect }\end{array}$ \\
\hline $\begin{array}{lr}2 . & \text { Differing } \\
\text { perceptions } & \text { among } \\
\text { school staff } & \end{array}$ & 0.74 & 2.40 & 1 & Small Extent & Rarely & $\begin{array}{l}\text { Rarely happening } \\
\text { with minor effect }\end{array}$ \\
\hline $\begin{array}{l}\text { 3. School climate } \\
\text { factors }\end{array}$ & 0.66 & 2.19 & 4 & Small Extent & Rarely & $\begin{array}{l}\text { Rarely happening } \\
\text { with minor effect }\end{array}$ \\
\hline $\begin{array}{l}\text { 4. Bullying between } \\
\text { school staff and } \\
\text { students }\end{array}$ & 0.84 & 2.07 & 7 & Small Extent & Rarely & $\begin{array}{l}\text { Rarely happening } \\
\text { with minor effect }\end{array}$ \\
\hline $\begin{array}{lr}5 . & \text { Ineffective } \\
\text { supervision of students }\end{array}$ & 0.81 & 2.32 & 3 & Small Extent & Rarely & $\begin{array}{l}\text { Rarely happening } \\
\text { with minor effect }\end{array}$ \\
\hline $\begin{array}{l}\text { 6. Lack of time for } \\
\text { other school staff to } \\
\text { consistently address } \\
\text { bullying }\end{array}$ & 0.79 & 2.18 & 5 & Small Extent & Rarely & $\begin{array}{l}\text { Rarely happening } \\
\text { with minor effect }\end{array}$ \\
\hline $\begin{array}{l}\text { 7. Other staffs lack of } \\
\text { knowledge or skills to } \\
\text { effectively intervene }\end{array}$ & 0.73 & 2.09 & 6 & Small Extent & Rarely & $\begin{array}{l}\text { Rarely happening } \\
\text { with minor effect }\end{array}$ \\
\hline $\begin{array}{l}\text { 8. Lack of resources } \\
\text { and / or administrative } \\
\text { support }\end{array}$ & 0.83 & 2.33 & 2 & Small Extent & Rarely & $\begin{array}{l}\text { Rarely happening } \\
\text { with minor effect }\end{array}$ \\
\hline Over all & 0.597 & 2.208 & & Small Extent & Rarely & $\begin{array}{l}\text { Rarely happening } \\
\text { with minor effect }\end{array}$ \\
\hline
\end{tabular}

Legend:3.50 - 4.00 - Always, Great Extent, Very frequently, happening with major effect; 2.50 - 3.49 - Often, Moderate Extent, Frequently happening with moderate effect; 1.50 - 2.49 - Rarely, Small Extent, Rarely happening with minor effect; 1.00 - 1.49 - Never, Not a concern, Not happening with no effect at all of 0.79, other staffs' lack of knowledge and skills to effectively intervene with a mean of 2.09 and a standard deviation of 0.73 , bullying between staff and students with a mean of 2.07and a standard deviation of 0.84 , and lastly, ineffective discipline policies with a mean of 2.06 and a standard deviation of 0.71 . All statement were assessed as rarely, small extent, 
rarely happening with minor effect. An overall mean of 2.208 and standard deviation of 0.597 , rarely, with small extent, rarely happening with minor effect is assessed by CPC-respondents.

Consistent with the social-ecological framework (Espelage \& Swearer, 2008), schools should address their social environment and the broader culture and climate of bullying. Given the links between bullying and school climate (Swearer et al., 2010), activities that improve the various facets of school climate (e.g., safety, engagement, environment) will likely translate into reductions in bullying, and may increase high quality implementation of research- based programs (Bradshaw, Koth et al., 2009; Domitrovich et al., 2008). However, efforts aimed at improving school climate require sustained and intensive commitment from all students, staff, families, and the community. Related research has documented the importance of school wide prevention efforts that provide consistent positive behavior supports, establish a common set of expectations for positive behavior across all school contexts, and involve all school staff in prevention activities (Bradshaw, 2013).

Table 12 reflects the CPC-respondents' assessment on community-based barriers in bullying interventions. The result shows that differing behavioral expectations, with a mean of 2.80 and a standard deviation of 0.72 is considered by CPC-respondents as the main community-based barrier followed by prevalence of bullying occurring outside the school and parents' reaction to bullying both have a mean of 2.78 with a standard deviation of $0.73,0.72$ respectively, followed by perception of bullying among community members with a mean of 2.62 and a standard deviation of 0.67, All community-based barriers are assessed by CPC-respondents as often, with moderate extent and frequently happening with moderate effect. An overall mean of 2.746 and standard deviation of 0.604 , often, with moderate extent and frequently happening with moderate effect, is assessed by CPC-respondents on community-based barriers.

Table 12:-CPC-Respondents Assessment on Community-Based Barriers to Bullying Interventions

\begin{tabular}{|l|l|l|l|l|l|l|}
\hline Statement SD & Mean & Rank & $\begin{array}{l}\text { Qualitative } \\
\text { Interpretation }\end{array}$ & Scale & $\begin{array}{l}\text { Descriptive } \\
\text { Interpretation }\end{array}$ \\
\hline $\begin{array}{l}\text { 1. Parent's reaction to } \\
\text { bullying }\end{array}$ & 0.72 & 2.78 & 2.5 & Moderate Extent & Often & $\begin{array}{l}\text { Frequently } \\
\text { happening with } \\
\text { moderate effect }\end{array}$ \\
\hline $\begin{array}{l}\text { 2. Prevalence of } \\
\text { bullying occurring } \\
\text { outside of school }\end{array}$ & 0.73 & 2.78 & 2.5 & Moderate Extent & Often & $\begin{array}{l}\text { Frequently } \\
\text { happening with } \\
\text { moderate effect }\end{array}$ \\
\hline $\begin{array}{l}\text { 3. Differing behavioral } \\
\text { expectations }\end{array}$ & 0.72 & 2.80 & 1 & Moderate Extent & Often & $\begin{array}{l}\text { Frequently with } \\
\text { happening woderate effect } \\
\text { moder }\end{array}$ \\
\hline $\begin{array}{l}\text { 4. Perception of } \\
\text { bullying } \\
\text { community members. }\end{array}$ & 0.67 & 2.62 & 4 & Moderate Extent & Often & $\begin{array}{l}\text { Frequently } \\
\text { happening with } \\
\text { moderate effect }\end{array}$ \\
\hline $\begin{array}{l}\text { Over all } \\
\text { momong with }\end{array}$ \\
\hline
\end{tabular}

Legend:3.50 - 4.00 - Always, Great Extent, Very frequently, happening with major effect; 2.50 - 3.49 - Often, Moderate Extent, Frequently happening with moderate effect; 1.50 - 2.49 - Rarely, Small Extent, Rarely happening with minor effect; $1.00-1.49$ - Never, Not a concern, Not happening with no effect at all

Consistent with the ecological model, Bradshaw's research in 2014 suggests that programs which include some type of family component are most effective at preventing bullying. Families play a critical role by providing emotional support to promote disclosure of bullying incidents and by fostering coping skills in their children (Bradshaw, 2014). Parents appear to benefit from training in how to talk with their children about bullying, how to communicate their concerns about bullying to the school, and ways to get actively involved in school-based prevention efforts (Waasdorp, Bradshaw, \& Duong, 2011). Yet, recent research suggests that simply having dinner together on a regular basis (i.e., 4 or more times a week) can serve as a buffer for the negative effects associated with bullying (Elgar et al., 2014). Although an understudied area, there are also bullying prevention activities that can occur at the 
community level, such as awareness or social marketing campaigns that encourage all youth and adults (e.g., doctors, police officers) to intervene when they see bullying and become actively involved in school- and community-based prevention activities (Holt, Raczynskib, Frey, Hymel, \& Limber, 2013). Such programs and strategies aim to shift norms related to bullying and aggressive responses to threat, but there has been little to no research on their effectiveness.

Table 13 presents the teacher-respondents constructive-direct responses to school-based bullying. The result shows that use personal experience with bullying with a mean of 3.84 and a standard deviation of 0.78 , always, in most case, very frequent response, is considered by teacher-respondent as the main constructive-direct response in bullying followed by protect the victim with a mean of 3.33 and a standard deviation of 0.75 , often, in several cases, frequent response, make bully apologized with a mean of 3.23 and a standard deviation of 0.80 , often, in several cases, frequent response, call out for inappropriate behavior with a mean of 3.07 and a standard deviation of 0.80, often, in several cases, frequent response, pull aside and talk to student(s), with a mean of 3.05, and a standard deviation of 0.76 , often, in several cases, frequent response.

Table 13:-Teacher-Respondents Constructive-Direct Responses to School-Based Bullying

\begin{tabular}{|c|l|l|l|l|l|l|}
\hline Statement & SD & Mean & Rank & $\begin{array}{l}\text { Qualitative } \\
\text { Interpretation }\end{array}$ & Scale & $\begin{array}{l}\text { Descriptive } \\
\text { Interpretation }\end{array}$ \\
\hline $\begin{array}{c}\text { 1. Pull aside } \\
\text { and talk to } \\
\text { student(s) }\end{array}$ & 0.76 & 3.05 & 5 & In several cases & Often & Frequent response \\
\hline $\begin{array}{c}\text { 2. } \begin{array}{l}\text { Call out } \\
\text { inappropriat } \\
\text { e behavior }\end{array} \\
\text { Protect the } \\
\text { victim }\end{array}$ & 0.80 & 3.07 & 4 & In several cases & Often & Frequent response \\
\hline $\begin{array}{l}\text { Make bully } \\
\text { apologize }\end{array}$ & 0.80 & 3.23 & 3 & In several cases & Often & Frequent response \\
\hline $\begin{array}{l}\text { 5se } \\
\text { personal } \\
\text { experience } \\
\text { with } \\
\text { bullying }\end{array}$ & 0.78 & 3.84 & 1 & In most cases & Always & Very frequent response \\
\hline Over all & 0.578 & 3.103 & & In several cases & Often & Frequent response \\
\hline
\end{tabular}

Legend:3.50 - 4.00 - Always, In most cases, Very frequent response ; 2.50 - 3.49 - Often, In several cases, Frequent response 1.50 - 2.49 - Seldom, In seldom cases, Rare response; 1.00 - 1.49 - Never, Not a concern, No response

An overall mean of 3.103 and standard deviation of 0.578 , often, in several cases, frequent response, is assessed by teacher-respondents on constructive-direct responses.

Marshalls' study in 2012 noted inadequacy may account in part for prior research findings indicating that teachers do not consistently intervene in incidents of bullying (Sairanen \& Pfeffer, 2011). Similar to previous research (e.g., Bauman et al., 2008; Mishna et al., 2005; Yoon, Bauman, Choi, \& Hutchinson, 2011), majority of the participants in this study indicated they had not received anti-bullying training. These findings lend credence to assertions made by both teachers and researchers regarding the ongoing need and desire for additional training about bullying. Thus, better preparing teachers to address bullying may be one way to maximize effective intervention. Many teachers in this study also reported experiencing school-related barriers, such as ineffective and inconsistent discipline policies regarding bullying, as well as a lack of school-based resources and administrative support. The importance of implementing explicit anti-bullying policies and providing consistent administrative support for teachers has been stressed by researchers and teachers (Mishna et al., 2005; Swearer, Espelage \& Napolitano, 2009; Twemlow \& Sacco, 2010).

Table 14 presents the teacher-respondents constructive-indirect responses to school-based bullying. The result shows that call victim's parent with a mean of 3.36 and a standard deviation of 0.77 , always, in most case, very frequent 
response, is considered by teacher-respondent as the main constructive-direct response in bullying followed by send, inform or refer student(s) to counselor with a mean of 3.15 and a standard deviation of 0.77 , often, in several cases, frequent response, consult other educators with a mean of 3.02 and a standard deviation of 0.77 , often, in several cases, frequent response. An overall mean of 3.146 and standard deviation of 0.650 , often, in several cases, frequent response, is assessed by teacher-respondents on constructive-indirect responses.

Table 14:-Teacher-Respondents Constructive-Indirect Responses to School- Based Bullying

\begin{tabular}{|l|l|l|l|l|l|l|}
\hline Statement & SD & Mean & Rank & $\begin{array}{l}\text { Qualitative } \\
\text { Interpretation }\end{array}$ & Scale & Descriptive Interpretation \\
\hline $\begin{array}{l}\text { 1. Send, inform or } \\
\text { refer student(s) } \\
\text { to counselor }\end{array}$ & 0.77 & 3.15 & 2 & In several cases & Often & Frequent response \\
\hline $\begin{array}{l}\text { 2onsult other } \\
\text { educators }\end{array}$ & 0.77 & 3.02 & 3 & In several cases & Often & Frequent response \\
\hline \begin{tabular}{l} 
3. $\begin{array}{l}\text { Call victim's } \\
\text { parents }\end{array}$ \\
\hline Over all
\end{tabular} & 0.77 & 3.26 & 1 & In several cases & Often & Frequent response \\
\hline
\end{tabular}

Legend:3.50 - 4.00 - Always, In most cases, Very frequent response ; 2.50 - 3.49 - Often, In several cases, Frequent response

\subsection{0 - 2.49 - Seldom, In seldom cases, Rare response; 1.00 - 1.49 - Never, Not a concern, No response}

For instance, in a qualitative study with teachers, Mishna and colleagues (2005) found that the majority of participants reported not knowing how to respond effectively to indirect bullying (i.e., non-physical behaviors) due to the absence of a school policy providing guidelines for their responses (as opposed to confronting direct types of bullying such as hitting or pushing for which there were standard procedures to follow). Findings from the current study support the recommendation that in order to enhance teachers ${ }^{\text {ee }}$ responses to bullying, schools need to adopt clear and consistent policies and procedures regarding bullying, as well as provide teachers with accessible resources and supportive leadership.

Table 15 presents the teacher-respondents punitive-direct responses to school-based bullying. The result shows that remove or move bully in the classroom with a mean of 2.59 and a standard deviation of 0.92 , often, in several cases, frequent response, is considered by teacher-respondent as the main punitive-direct response in bullying followed by punishment with a mean of 2.37 and a standard deviation of 0.93 seldom, in several cases, rare response, physically get in the middle of the students with a mean of 2.34 and a standard deviation of 0.92 , seldom, in several cases, rare response, yell with a mean of 2.05 and a standard deviation of 0.97 , seldom, in several cases, rare response. An overall mean of 2.338 and a standard deviation of 0.685 , is assessed by teacher-respondents on punitive-direct responses.

Table 15:-Teacher-Respondents Punitive-Direct Responses to School-Based Bullying

\begin{tabular}{|l|l|l|l|l|l|l|}
\hline Statement SD & Mean & Rank & $\begin{array}{l}\text { Qualitative } \\
\text { Interpretation }\end{array}$ & Scale & $\begin{array}{l}\text { escriptive } \\
\text { Interpretation }\end{array}$ \\
\hline $\begin{array}{l}\text { 1. Remove or move } \\
\text { bully in the } \\
\text { classroom }\end{array}$ & 0.92 & 2.59 & 1 & In several cases & Often & $\begin{array}{l}\text { Frequent } \\
\text { response }\end{array}$ \\
\hline 2. Punishment & 0.93 & 2.37 & 2 & In seldom cases & Seldom & Rare response \\
\hline $\begin{array}{l}\text { 3. Physically get in } \\
\text { the middle of } \\
\text { students }\end{array}$ & 0.92 & 2.34 & 3 & In seldom cases & Seldom & Rare response \\
\hline 4. Yell & 0.97 & 2.05 & 4 & In seldom cases & Seldom & Rare response \\
\hline Over all & 0.685 & 2.338 & & In seldom cases & Seldom & Rare response \\
\hline
\end{tabular}

Legend:

$3.50-4.00$ - Always, In most cases, Very frequent response 
2.50 - 3.49 - Often, In several cases, Frequent response

$1.50-2.49$ - Seldom, In seldom cases, Rare response

1.00 - 1.49 - Never, Not a concern, No response

Table 16 presents the teacher-respondents punitive-indirect responses to school-based bullying. The result shows that call bully's parent with a mean of 3.17 and a standard deviation of 0.81 , often, in several cases, frequent response, is considered by teacher-respondent as the main punitive-indirect response in bullying followed by send, inform or refer students to school administrator with a mean of 2.97 and a standard deviation of 0.82 , often, in several cases, frequent response. An overall mean of 3.071 and a standard deviation of 0.719 , often, in several cases, frequent response is assessed by teacher-respondents on punitive-indirect responses.

Table 16:-Teacher-Respondents Punitive-Indirect Responses to School-Based Bullying

\begin{tabular}{|l|l|l|l|l|l|l|}
\hline Statement & SD & Mean & Rank & $\begin{array}{l}\text { Qualitative } \\
\text { Interpretation }\end{array}$ & Scale & $\begin{array}{l}\text { Descriptive } \\
\text { Interpretation }\end{array}$ \\
\hline 1. Call bully's parents & 0.81 & 3.17 & 1 & In several cases & Often & $\begin{array}{l}\text { Frequent } \\
\text { response }\end{array}$ \\
\hline $\begin{array}{l}\text { 2. Send, inform or } \\
\text { refer bully to } \\
\text { school } \\
\text { administrator }\end{array}$ & 0.82 & 2.97 & 2 & In several cases & Often & $\begin{array}{l}\text { Frequent } \\
\text { response }\end{array}$ \\
\hline Over all & 0.719 & 3.071 & & In several cases & Often & $\begin{array}{l}\text { Frequent } \\
\text { response }\end{array}$ \\
\hline
\end{tabular}

Legend:3.50 - 4.00 - Always, In most cases, Very frequent response ; 2.50 - 3.49 - Often, In several cases, Frequent response

1.50 - 2.49 - Seldom, In seldom cases, Rare response; 1.00 - 1.49 - Never, Not a concern, No response

Table 17 presents the CPC-respondents constructive-direct responses to school-based bullying. The result shows that protect the victim with a mean of 3.46 and a standard deviation of 0.71 , often, in several cases, frequent response, is considered by CPC-respondent as the main constructive-direct response in bullying followed by make bully apologize with a mean of 3.14 and a standard deviation of 0.83 , often, in several cases, frequent response, pull aside and talk to student(s) with a mean of 3.08 and a standard deviation of 0.85 , often, in several cases, frequent response, call out for inappropriate behavior with a mean of 3.05 and a standard deviation of 0.71 , often, in several cases, frequent response, and use personal experience with bullying with a mean of 2.66, and a standard deviation of 0.75 , often, in several cases, frequent response. An overall mean of 3.078 and standard deviation of 0.560 , often, in several cases, frequent response, is assessed by CPC-respondents on constructive-direct responses.

Table 17:-CPC-Respondents Constructive-Direct Responses to School-Based Bullying

\begin{tabular}{|c|c|c|c|c|c|c|}
\hline Statement & SD & Mean & Rank & $\begin{array}{l}\text { Qualitative } \\
\text { Interpretation }\end{array}$ & Scale & $\begin{array}{l}\text { Descriptive } \\
\text { Interpretation }\end{array}$ \\
\hline $\begin{array}{l}\text { 1. Pull aside and talk to } \\
\text { student(s) }\end{array}$ & 0.85 & 3.08 & 3 & In several cases & Often & $\begin{array}{l}\text { Frequent } \\
\text { response }\end{array}$ \\
\hline $\begin{array}{l}\text { 2. Call out inappropriate } \\
\text { behavior }\end{array}$ & 0.71 & 3.05 & 4 & In several cases & Often & $\begin{array}{l}\text { Frequent } \\
\text { response }\end{array}$ \\
\hline 3. Protect the victim & 0.71 & 3.46 & 1 & In several cases & Often & $\begin{array}{l}\text { Frequent } \\
\text { response }\end{array}$ \\
\hline 4. Make bully apologize & 0.83 & 3.14 & 2 & In several cases & Often & $\begin{array}{l}\text { Frequent } \\
\text { response }\end{array}$ \\
\hline $\begin{array}{llr}\text { 5. Use } & \text { personal } \\
\text { experience } & \text { with } \\
\text { bullying } & \end{array}$ & 0.75 & 2.66 & 5 & In several cases & Often & $\begin{array}{l}\text { Frequent } \\
\text { response }\end{array}$ \\
\hline Over all & 0.560 & 3.078 & & In several cases & Often & $\begin{array}{l}\text { Frequent } \\
\text { response }\end{array}$ \\
\hline
\end{tabular}


Legend:3.50 - 4.00 - Always, In most cases, Very frequent response ;2.50 - 3.49 - Often, In several cases, Frequent response

1.50 - 2.49 - Seldom, In seldom cases, Rare response; 1.00 - 1.49 - Never, Not a concern, No response

Table 18 presents the CPC-respondents constructive-indirect responses to school-based bullying. The result shows that call victim's parent with a mean of 3.41 and a standard deviation of 0.77 , is considered by CPC-respondent as the main constructive-direct response in bullying followed by send, inform or refer student(s) to counselor with a mean of 3.37 and a standard deviation of 0.72 , consult other educators with a mean of 3.11 and a standard deviation of 0.73. All were assessed as, often, in several cases, frequent response. An overall mean of 3.295 and standard deviation of 0.637 , often, in several cases, frequent response, is assessed by CPC-respondents on constructiveindirect responses.

Table 18:-CPC-Respondents Constructive-Indirect Responses to School-Based Bullying

\begin{tabular}{|c|c|c|c|c|c|c|}
\hline Statement & SD & Mean & Rank & $\begin{array}{l}\text { Qualitative } \\
\text { Interpretation }\end{array}$ & Scale & $\begin{array}{l}\text { Descriptive } \\
\text { Interpretation }\end{array}$ \\
\hline $\begin{array}{l}\text { 1. Send, inform or } \\
\text { refer student(s) to } \\
\text { counselor }\end{array}$ & 0.72 & 3.37 & 2 & In several cases & Often & Frequent response \\
\hline $\begin{array}{ll}\text { 2. } & \begin{array}{l}\text { Consult } \\
\text { educators }\end{array} \\
\end{array}$ & 0.73 & 3.11 & 3 & In several cases & Often & Frequent response \\
\hline $\begin{array}{l}\text { 3. Call victim's } \\
\text { parents }\end{array}$ & 0.77 & 3.41 & 1 & In several cases & Often & Frequent response \\
\hline Over all & 0.637 & 3.295 & & In several cases & Often & Frequent response \\
\hline
\end{tabular}

Legend:3.50 - 4.00 - Always, In most cases, Very frequent response ; 2.50 - 3.49 - Often, In several cases, Frequent response

1.50 - 2.49 - Seldom, In seldom cases, Rare response; 1.00 - 1.49 - Never, Not a concern, No response

Table 19 presents the CPC-respondents punitive-direct responses to school-based bullying. The result shows that remove or move bully in the classroom with a mean of 2.74 and a standard deviation of 1.01 , often, in several cases, frequent response, is considered by CPC-respondent as the main punitive-direct response in bullying followed by punishment and physically get in the middle of the students both with a mean of 2.72 and a standard deviation of 0.84 and 0.97 respectively, often, in several cases, frequent response yell with a mean of 2.19 and a standard deviation of 0.91 , seldom, in seldom cases, rare response. An overall mean of 2.594 and a standard deviation of 0.677, often, in several cases, frequent response is assessed by CPC-respondents on punitive-direct responses.

Table 19:-CPC-Respondents Punitive-Direct Responses to School-Based Bullying

\begin{tabular}{|l|l|l|l|l|l|l|}
\hline Statement & SD & Mean & Rank & $\begin{array}{l}\text { Qualitative } \\
\text { Interpretation }\end{array}$ & Scale & $\begin{array}{l}\text { Descriptive } \\
\text { Interpretation }\end{array}$ \\
\hline $\begin{array}{l}\text { 1. } \\
\begin{array}{l}\text { Remove or move } \\
\text { bully in the } \\
\text { classroom }\end{array}\end{array}$ & 1.01 & 2.74 & 1 & In several cases & Often & Frequent response \\
\hline 2. Punishment & 0.84 & 2.72 & 2 & In several cases & Often & Frequent response \\
\hline \begin{tabular}{l} 
3. $\begin{array}{l}\text { Physically get in } \\
\text { the middle of } \\
\text { students }\end{array}$ \\
\hline Yell
\end{tabular} & 0.97 & 2.72 & 3 & In several cases & Often & Frequent response \\
\hline Over all & 0.677 & 2.594 & & In several cases & Often & Frequent response \\
\hline
\end{tabular}

Legend:

$3.50-4.00$ - Always, In most cases, Very frequent response

2.50 - 3.49 - Often, In several cases, Frequent response

1.50 - 2.49 - Seldom, In seldom cases, Rare response

$1.00-1.49$ - Never, Not a concern, No response 
Table 20 presents the CPC-respondents punitive-indirect responses to school-based bullying. The result shows that call bully's parent with a mean of 3.45 and a standard deviation of 0.75 , often, in several cases, frequent response, is considered by CPC-respondent as the main punitive-indirect response in bullying followed by send, inform or refer students to school administrator with a mean of 3.06 and a standard deviation of 0.78 , often, in several cases, frequent response. An overall mean of 3.255 and a standard deviation of 0.652 , often, in several cases, frequent response is assessed by CPC-respondents on punitive-indirect responses.

Table 20:-CPC-Respondents Punitive-Indirect Responses to School-Based Bullying

\begin{tabular}{|c|c|c|c|c|c|c|}
\hline Statement & SD & Mean & Rank & $\begin{array}{l}\text { Qualitative } \\
\text { Interpretation }\end{array}$ & Scale & $\begin{array}{l}\text { Descriptive } \\
\text { Interpretation }\end{array}$ \\
\hline $\begin{array}{l}\text { Call bully's } \\
\text { parents }\end{array}$ & 0.75 & 3.45 & 1 & In several cases & Often & $\begin{array}{l}\text { Frequent } \\
\text { response }\end{array}$ \\
\hline $\begin{array}{lll}\text { 2. Send, inform or } \\
\text { refer bully to } \\
\text { school } \\
\text { administrator }\end{array}$ & 0.78 & 3.06 & 2 & In several cases & Often & $\begin{array}{l}\text { Frequent } \\
\text { response }\end{array}$ \\
\hline Over all & 0.652 & 3.255 & & In several cases & Often & $\begin{array}{l}\text { Frequent } \\
\text { response }\end{array}$ \\
\hline
\end{tabular}

Legend: 3.50 - 4.00 - Always, In most cases, Very frequent response ; 2.50 - 3.49 - Often, In several cases, Frequent response

1.50 - 2.49 - Seldom, In seldom cases, Rare response; 1.00 - 1.49 - Never, Not a concern, No response

Table 21 reflects the teacher-respondents assessment on the bullying intervention programs in school. The result reveals that home visitation with a mean of 3.22 and a standard deviation of 0.68 is considered by teacherrespondents as the main intervention program in bullying intervention followed by values formation program with a mean of 3.20 and a standard deviation of 0.72 , students orientation with a mean of 3.18 and standard deviation of 0.69 , parents orientation with a mean of 3.17 and a standard deviation of 0.72 , peer mentoring / counselling with a mean of 3.12 and a standard deviation of 0.72 , community-student mentoring and zero-tolerance policy both with a mean of 2.97 and a standard deviation of 0.74 and 0.81 respectively, lastly, barangay ordinances against bullying with a mean of 2.97 and a standard deviation of 0.81 . All intervention programs in this study were assessed by teacher-respondents as good, effective with high impact. An overall mean of 3.097 and standard deviation of 0.551 good, effective with high impact is assessed by teacher-respondents on intervention programs in school. Bullying prevention must be part of a comprehensive, cohesive, and integrated school- wide system of learning supports that creates a cultural norm of safety, connectedness, acceptance, and support. Single, stand-alone bullying prevention programs tend not to be optimally effective or sustainable.

Table 21:-Teacher-Respondents Assessment on the Effectiveness of Bullying Intervention Programs in School

\begin{tabular}{|c|c|c|c|c|c|c|}
\hline Statement & SD & Mean & Rank & $\begin{array}{l}\text { Qualitative } \\
\text { Interpretation }\end{array}$ & Scale & $\begin{array}{l}\text { Descriptive } \\
\text { Interpretation }\end{array}$ \\
\hline $\begin{array}{l}\text { 1. Home visitation } \\
\text { policy }\end{array}$ & 0.68 & 3.22 & 1 & Effective & Good & High impact \\
\hline $\begin{array}{l}\text { 2. Peer mentoring / } \\
\text { counselling }\end{array}$ & 0.68 & 3.12 & 5 & Effective & Good & High impact \\
\hline $\begin{array}{ll}\text { 3. } & \text { Students } \\
\text { Orientation }\end{array}$ & 0.69 & 3.18 & 3 & Effective & Good & High impact \\
\hline 4. Parents Orientation & 0.72 & 3.17 & 4 & Effective & Good & High impact \\
\hline $\begin{array}{l}\text { 5. Values Formation } \\
\text { Program }\end{array}$ & 0.72 & 3.20 & 2 & Effective & Good & High impact \\
\hline $\begin{array}{ll}\text { 6. } & \text { Community - } \\
\text { student mentoring. }\end{array}$ & 0.74 & 2.97 & 6.5 & Effective & Good & High impact \\
\hline $\begin{array}{ll}\text { 7. } & \text { zero tolerance } \\
\text { policy } & \end{array}$ & 0.81 & 2.97 & 6.5 & Effective & Good & High impact \\
\hline
\end{tabular}




\begin{tabular}{|l|l|l|l|l|l|l|}
\hline \begin{tabular}{l} 
8. $\begin{array}{l}\text { Barangay } \\
\text { ordinances } \\
\text { against bullying. }\end{array}$ \\
\hline Over all
\end{tabular} & 0.82 & 2.95 & 8 & Effective & Good & High impact \\
\hline
\end{tabular}

Legend:3.50 - 4.00 - Very Good, Very effective, Very high impact; 2.50 - 3.49 - Good, Effective, High impact; $1.50-2.49$ - Fair,

Less effective, Slight impact; 1.00 - 1.49 - Poor, Ineffective, No impact

The result of the study is aligned with the NASP research in 2012 on prevention and intervention efforts • Ongoing engagement, evaluation, consistency, and commitment are necessary components to ensure sustainability. $\bullet$ Students and their families should be actively engaged in policy and program development and implementation. - The availability and accessibility of school- employed, specialized instructional support personnel with knowledge and training in creating safe schools (e.g., school psychologists, school counselors, school social workers, and school nurses) is paramount to improving school environments. - A school safety team-which focuses on overall school climate - must be established to help sustain efforts over time. - Staff training should reinforce the importance of bullying prevention and response efforts throughout all classroom and non-classroom interactions and settings (e.g., cafeteria, hallways, playground, digital media, bus stops, and school-sponsored events off school grounds). • Discipline policies should: be clear, consistent, and fair; safeguard the well-being of students and staff; $\mathrm{n}$ teach students alternative, positive behaviors; avoid harsh discipline and overly punitive policies (e.g., zero tolerance); and $\mathrm{n}$ cover before and after-school activities, as well as bullying and harassment via digital media.

Consistent with previous studies (Domitrovich et al., 2008; Durlak, Weissberg, Dymnicki, Taylor, \& Schellinger, 2011; Olweus, 2005), program dosage and fidelity were functionally associated with program impacts. Although this study shed some light on the most efficacious elements, it is important to note that additional research is needed to actually test and isolate the critical components of effective bullying prevention programs.

Table 22 reflects the teacher-respondents assessment on the bullying intervention strategies in school. The result reveals that providing teachers with effective classroom management training with a mean of 3.15 and a standard deviation of 0.65 is considered by teacher-respondents as the main intervention strategies in bullying intervention followed by school administrators / guidance counselors inform late- enrolling students about the school's bullying policy with a mean of 3.11 and a standard deviation of 0.67 , strengthening information drive regarding bullying with a mean 3.07 of and a standard deviation of 0.68 , training students in conflict resolution and peer mediation with a mean of 2.95 and a standard deviation of 0.68 , monitoring areas where bullying can be expected with a mean 2.96 of and a standard deviation of 0.72 , posting classroom signs prohibiting bullying and listing the consequences for it with a mean 2.95 of and a standard deviation of 0.72, encouraging victims to simply "stand up" to bullies with a mean of 2.92 and a standard deviation of 0.71 , increasing student reporting of bullying with a mean of 2.81 and a standard deviation of 0.70 , providing group therapy for bullies with a mean of 2.81 and a standard deviation of 0.76 , reducing the amount of time students can spend less supervised with a mean of 2.76 and a standard deviation of 0.65 , developing activities in less- supervised areas and assigning bullies to a particular location or to particular chores during release times both with a mean of 2.74 and a standard deviation of 0.68 and 0.74 respectively and lastly, staggering recess, lunch and/or class- release times with a

Table 22:-Teacher-Respondents Assessment on the Effectiveness of Bullying Intervention Strategies in School

\begin{tabular}{|l|l|l|l|l|l|l|}
\hline Statement & SD & Mean & Rank & $\begin{array}{l}\text { Qualitative } \\
\text { Interpretation }\end{array}$ & Scale & $\begin{array}{l}\text { Descriptive } \\
\text { Interpretation }\end{array}$ \\
\hline $\begin{array}{l}\text { 1. Increasing student } \\
\text { reporting of bullying }\end{array}$ & 0.70 & 2.81 & 8 & Effective & Good & High impact \\
\hline 2. $\begin{array}{l}\text { Developing activities in } \\
\text { less- supervised areas }\end{array}$ & 0.68 & 2.74 & 11.5 & Effective & Good & High impact \\
\hline $\begin{array}{l}\text { 3. } \\
\begin{array}{l}\text { Reducing the amount of } \\
\text { time students can spend } \\
\text { less supervised }\end{array}\end{array}$ 0.65 & 2.76 & 10 & Effective & Good & High impact \\
\hline 4. Staggering recess, lunch & 0.68 & 2.73 & 13 & Effective & Good & High impact \\
\hline
\end{tabular}




\begin{tabular}{|c|c|c|c|c|c|c|}
\hline and/or class- release times & & & & & & \\
\hline $\begin{array}{l}\text { 5. Monitoring areas where } \\
\text { bullying can be expected } \\
\text { (e.g., bathrooms) }\end{array}$ & 0.72 & 2.96 & 5 & Effective & Good & High impact \\
\hline $\begin{array}{l}\text { 6. Assigning bullies to a } \\
\text { particular location or to } \\
\text { particular chores during } \\
\text { release times }\end{array}$ & 0.74 & 2.74 & 11.5 & Effective & Good & High impact \\
\hline $\begin{array}{l}\text { 7. Posting classroom signs } \\
\text { prohibiting bullying and } \\
\text { listing the consequences } \\
\text { for it }\end{array}$ & 0.72 & 2.95 & 6 & Effective & Good & High impact \\
\hline $\begin{array}{l}\text { 8. Providing teachers with } \\
\text { effective classroom } \\
\text { management training }\end{array}$ & 0.67 & 3.15 & 1 & Effective & Good & High impact \\
\hline $\begin{array}{l}\text { 9. School administrators / } \\
\text { Guidance Counselors } \\
\text { inform late- enrolling } \\
\text { students about the school's } \\
\text { bullying policy }\end{array}$ & 0.67 & 3.11 & 2 & Effective & Good & High impact \\
\hline $\begin{array}{l}\text { 10. Training students in } \\
\text { conflict resolution and } \\
\text { peer mediation }\end{array}$ & 0.68 & 2.95 & 4 & Effective & Good & High impact \\
\hline $\begin{array}{l}\text { 11. Providing group therapy } \\
\text { for bullies }\end{array}$ & 0.76 & 2.81 & 9 & Effective & Good & High impact \\
\hline $\begin{array}{l}\text { 12. Encouraging victims } \\
\text { simply "stand up" } \\
\text { bullies }\end{array}$ & 0.71 & 2.92 & 7 & Effective & Good & High impact \\
\hline $\begin{array}{l}\text { 13. Strengthening information } \\
\text { drive regarding bullying }\end{array}$ & 0.68 & 3.07 & 3 & Effective & Good & High impact \\
\hline Overall & 0.652 & 2.899 & & Effective & Good & High impact \\
\hline
\end{tabular}

Legend:3.50 - 4.00 - Very Good, Very effective, Very high impact;2.50 - 3.49 - Good, Effective, High impact;1.50 - 2.49 - Fair, Less effective, Slight impact ; 1.00 - 1.49 - Poor, Ineffective, No impactof 2.73 and a standard deviation of 0.68 . All intervention strategies in this study were assessed by teacher-respondents as good, effective with high impact. An overall mean of 2.899 and standard deviation of 0.652 , good, effective with high impact is assessed by teacher-respondents on intervention strategies in school.

The review by Farrington and Ttofi (2009) was also instructive in that it identified a number of factors associated with the effectiveness of bullying prevention programs. For example, they found that some of the core elements of effective programs included management approaches, such as high levels of playground supervision, use of consistent disciplinary methods, and classroom management strategies. Classroom and school wide rules related to bullying and training of teachers were also identified as common elements of effective programs. Another effective element included the use of parent training activities, meetings, and information, although these activities tended to be relatively "light touch" (e.g., disseminating informational material about bullying).

The result of this study is supported by the study of Espero and Espinosa in 2008, noted that guidance counselors should incorporate a program which teaches skills and strategies to avoid victimization. This can be conducted during group guidance classes. The topic which should be addressed first must be about recognizing the bullying behaviors. The students need to learn to differentiate bullying from the usual playful teasing or petty quarrels by knowing the definition of bullying and its different forms. The second topic should be on how to refuse bullying. Appropriate ways to handle bullies should be discussed and demonstrated through role plays in class. The last topic 
should be on reporting bullying incidents. Bullying incidents should be reported to the homeroom adviser, subject teacher, or guidance counselor. The students must know the necessary facts or information needed in reporting a bullying incident so that proper and immediate action can be taken by the school authority.

Table 23 reflects the CPC-respondents assessment on the bullying intervention programs in school.

Table 23:-CPC-Respondents Assessment on the Effectiveness of Bullying Intervention Programs in School

\begin{tabular}{|l|l|l|l|l|l|l|}
\hline Statement SD & Mean & Rank & $\begin{array}{l}\text { Qualitative } \\
\text { Interpretation }\end{array}$ & Scale & $\begin{array}{l}\text { Descriptive } \\
\text { Interpretation }\end{array}$ \\
\hline $\begin{array}{l}\text { 1. Home visitation } \\
\text { policy }\end{array}$ & 0.59 & 3.14 & 7 & Effective & Good & High impact \\
\hline $\begin{array}{l}\text { 2.er mentoring / } \\
\text { counselling }\end{array}$ & 0.71 & 3.28 & 4 & Effective & Good & High impact \\
\hline $\begin{array}{l}\text { 3. } \\
\text { Orientation }\end{array}$ & 0.63 & 3.46 & 1 & Effective & Good & High impact \\
\hline 4. Parents Orientation & 0.58 & 3.34 & 3 & Effective & Good & High impact \\
\hline \begin{tabular}{l} 
5. $\begin{array}{l}\text { Values Formation } \\
\text { Program }\end{array}$ \\
\hline $\begin{array}{l}\text { Community - student } \\
\text { mentoring. }\end{array}$
\end{tabular} 0.64 & 3.41 & 2 & Effective & Good & High impact \\
\hline $\begin{array}{l}\text { zero tolerance } \\
\text { policy }\end{array}$ & 0.62 & 3.15 & 5.5 & Effective & Good & High impact \\
\hline $\begin{array}{l}\text { Barangay } \\
\text { ordinances against } \\
\text { bullying. }\end{array}$ & 0.63 & 3.12 & 8 & Effective & Good & High impact \\
\hline Over all & 0.457 & 3.256 & & Effective & Good & High impact \\
\hline
\end{tabular}

Legend:3.50 - 4.00 - Very Good, Very effective, Very high impact; 2.50 - 3.49 - Good, Effective, High impact;1.50

- 2.49 - Fair, Less effective, Slight impact ; 1.00 - 1.49 - Poor, Ineffective, No impact

The result reveals that students' orientation with a mean of 3.46 and a standard deviation of 0.63 is considered by CPC-respondents as the main intervention program in bullying intervention followed by values formation program with a mean of 3.41 and a standard deviation of 0.64 , parents orientation with a mean of 3.34 and standard deviation of 0.58 , peer mentoring / counselling with a mean of 3.28 and a standard deviation of 0.71 , community - student mentoring and zero tolerance policy both with a mean of 3.15 and a standard deviation of 0.56 and 0.62 respectively, lastly, barangay ordinances against bullying with a mean of 3.12 and a standard deviation of 0.63 . All intervention programs in this study were assessed by CPC-respondents as good, effective with high impact. An overall mean of 3.56 and standard deviation of 0.457, good, effective with high impact is assessed by CPC-respondents on intervention programs in school.

Isava et. al. 2008 study noted that although anti-bullying interventions appear to be useful in increasing awareness, knowledge, and self-perceived competency in dealing with bullying, it should not be expected that these interventions will dramatically influence the incidence of actual bullying and victimization behaviors, or that they will positively influence even a majority of the targeted outcomes. In fact, our evidence indicates that the majority of targeted outcomes in school bullying interventions may not be significantly impacted, either positively or negatively.

In contrast to the more optimistic conclusions based on the rigorous review by Farrington and Ttofi (2009), some of the other systematic reviews of bullying prevention programs have generally been less favorable (Ferguson et al., 2007; Merrell et al., 2008). For example, Merrell et al. conducted a meta-analysis of 16 school-based bullying intervention studies and concluded that the interventions only produced a significant and "meaningful" impact on one third of the bullying-related outcomes examined. It is likely that the different conclusions drawn across the various systematic reviews is due to the variation in the methodology used to select studies for inclusion in the review (e.g., language or type of publication, sample size, a focus on North America, indicator of bullying; see Ttofi et al., 2014, for a detailed contrast as cited by Bradshaw, 2015). 
Table 24 reflects the CPC-respondents assessment on the bullying intervention strategies in school. The result reveals that school administrators / guidance counselors inform late- enrolling students about the school's bullying policy with a mean of 3.37 and a standard deviation of 0.64 is considered by CPC-respondents as the main intervention strategies in bullying intervention followed by providing teachers with effective classroom management training with a mean of 3.26 and a standard deviation of 0.63 , posting classroom signs prohibiting bullying and listing the consequences for it with a mean 3.14 of and a standard deviation of 0.76 , monitoring areas where bullying can be expected with a mean of 3.02 and a standard deviation of 0.66 , strengthening information drive regarding bullying with a mean 2.97 of and a standard deviation of 0.67 , training students in conflict resolution and peer mediation with a mean 2.96 of and a standard deviation of 0.57 , increasing student reporting of bullying with a mean of 2.95 and a standard deviation of 0.67 , assigning bullies to a particular location or to particular chores during release times.

Table 24:-CPC-Respondents Assessment on the Effectiveness of Bullying Intervention Strategies in School

\begin{tabular}{|c|c|c|c|c|c|c|}
\hline Statement & SD & Mean & Rank & $\begin{array}{l}\text { Qualitative } \\
\text { Interpretation }\end{array}$ & Scale & $\begin{array}{l}\text { Descriptive } \\
\text { Interpretation }\end{array}$ \\
\hline $\begin{array}{llr}\text { 1. } & \begin{array}{l}\text { Increasing } \\
\text { reporting }\end{array} & \text { student } \\
\text { bullying } & \text { of } \\
\end{array}$ & 0.67 & 2.95 & 7 & Effective & Good & High impact \\
\hline $\begin{array}{l}\text { 2. Developing } \\
\text { activities in less- } \\
\text { supervised areas }\end{array}$ & 0.60 & 2.90 & 9.5 & Effective & Good & High impact \\
\hline $\begin{array}{l}\text { 3. } \\
\text { Reducing the } \\
\text { amount of time } \\
\text { students can spend } \\
\text { less supervised }\end{array}$ & 0.67 & 2.89 & 11 & Effective & Good & High impact \\
\hline $\begin{array}{l}\text { 4. Staggering recess, } \\
\text { lunch and/or class- } \\
\text { release times }\end{array}$ & 0.62 & 2.88 & 12 & Effective & Good & High impact \\
\hline $\begin{array}{l}\text { 5. Monitoring areas } \\
\text { where bullying can } \\
\text { be expected (e.g., } \\
\text { bathrooms) }\end{array}$ & 0.66 & 3.02 & 4 & Effective & Good & High impact \\
\hline $\begin{array}{l}\text { 6. Assigning bullies to } \\
\text { a particular location } \\
\text { or to particular } \\
\text { chores during } \\
\text { release times }\end{array}$ & 0.75 & 2.94 & 8 & Effective & Good & High impact \\
\hline $\begin{array}{l}\text { 7. Posting classroom } \\
\text { signs prohibiting } \\
\text { bullying and listing } \\
\text { the consequences } \\
\text { for it }\end{array}$ & 0.76 & 3.14 & 3 & Effective & Good & High impact \\
\hline $\begin{array}{l}\text { 8. Providing teachers } \\
\text { with effective } \\
\text { classroom } \\
\text { management } \\
\text { training } \\
\end{array}$ & 0.63 & 3.26 & 2 & Effective & Good & High impact \\
\hline $\begin{array}{l}\text { 9. School } \\
\text { administrators } \\
\text { Guidance } \\
\text { Counselors inform }\end{array}$ & 0.64 & 3.37 & 1 & Effective & Good & High impact \\
\hline
\end{tabular}




\begin{tabular}{|l|l|l|l|l|l|l|}
\hline $\begin{array}{l}\text { late- } \\
\text { students enrolling } \\
\text { school's bultying } \\
\text { policy }\end{array}$ & & & & & & \\
\hline $\begin{array}{l}\text { 10. Training students in } \\
\text { conflict resolution } \\
\text { and peer mediation }\end{array}$ & 0.57 & 2.96 & 6 & Effective & Good & High impact \\
\hline $\begin{array}{l}\text { 11. Providing group } \\
\text { therapy for bullies }\end{array}$ & 0.59 & 2.85 & 13 & Effective & Good & High impact \\
\hline $\begin{array}{l}\text { 12. Encouraging } \\
\text { victims to simply } \\
\text { "stand up" to bullies }\end{array}$ & 0.67 & 2.90 & 9.5 & Effective & Good & High impact \\
\hline $\begin{array}{l}\text { 13. Strengthening } \\
\text { information drive } \\
\text { regarding bullying }\end{array}$ & 0.67 & 2.97 & 5 & Effective & Good & High impact \\
\hline Overall & 0.426 & 3.001 & & Effective & Good & High impact \\
\hline
\end{tabular}

Legend: 3.50 - 4.00 - Very Good, Very effective, Very high impact; 2.50 - 3.49 - Good, Effective, High impact; 1.50 - 2.49 - Fair, Less effective, Slight impact; 1.00 - 1.49 - Poor, Ineffective, No impact

with a mean of 2.94 and a standard deviation of 0.75, developing activities in less- supervised areas and encouraging victims to simply "stand up" to bullies both with a mean of 2.90 and a standard deviation of 0.60 and 0.67 respectively, reducing the amount of time students can spend less supervised with a mean of 2.89 and a standard deviation of 0.67, staggering recess, lunch and/or class- release times with a mean of 2.88 and a standard deviation of 0.62 and lastly, providing group therapy for bullies with a mean of 2.85 and a standard deviation of 0.59. All intervention strategies in this study were assessed by CPC-respondents as good, effective with high impact. An overall mean of 3.001 and standard deviation of 0.426, good, effective with high impact is assessed by CPCrespondents on intervention strategies in school.

Ancho and Park (2013) study suggested conducting lectures on nonviolence and human rights education as a compulsory part of the curriculum serves as a strategic move in instilling values among students. It also works for teachers and school personnel since it would help them work with the theories and principles of peace and interpersonal relationship. The Philippine education system could also incorporate classes in values education, social studies, physical education, and language education, among others with discussion on peer relation, respect and nonviolence. Lee as cited by Ancho and Park (2013) suggested that schools adopt a policy that highlights the character-building virtues such as respect, caring tolerance, and responsibility for others. The most effective (school) interventions appear to be those aimed at improving social and interpersonal skills and modifying attitudes and beliefs.

A study conducted by Altun and Baker in 2010 also support conducting seminal workshops on anger- management along with lessons on puberty stage. A recent study also notes that schools who enjoy non-violence observe a variety of activities participated in by students, as opposed to those institutions who stress control and punishment (Bickmore, 2011).

Table 25 presents the teacher-respondents assessment on the relationship between teacher-related factors and barriers to bullying intervention. 
Table 29:-Relationship between Teacher-Related Factors and Barriers to Bullying Interventions

\begin{tabular}{|lcccccccccc|}
\hline $\begin{array}{c}\text { Teacher-respondents' } \\
\text { assessment of barriers to } \\
\text { bullying interventions }\end{array}$ & Age & Gender & Civil Status & Length of Service & $\begin{array}{c}\text { Educational } \\
\text { Attainment }\end{array}$ \\
\cline { 2 - 11 } & & P-value & $r$ & P-value & $r$ & P-value & $r$ & P-value & $r$ & P-value \\
\hline Student-based barriers & 0.039 & 0.06 & 0.015 & 0.496 & 0.064 & $0.004^{* *}$ & 0.042 & $0.042^{*}$ & 0.038 & 0.072 \\
\hline Teacher-based barriers & 0.061 & $0.003^{* *}$ & -0.38 & 0.097 & 0.073 & $0.001^{* *}$ & 0.077 & $<0.0001^{* *}$ & 0.04 & 0.064 \\
\hline School-based barriers & 0.04 & 0.051 & -0.036 & 0.107 & 0.081 & $<0.0001^{* *}$ & 0.07 & $0.001^{* *}$ & 0.049 & $0.020^{*}$ \\
\hline Community-based barriers & -0.02 & 0.339 & -0.017 & 0.462 & 0.003 & 0.887 & 0.01 & 0.645 & 0.018 & 0.41
\end{tabular}

Legend $*$ significant $* *$ highly significant

The data reveals that in terms of age, teacher-based barriers with a P-value of 0.003 is found highly significant. As to gender, the result shows that no barriers have found significant, the P-value is all greater than 0.05 . As to civil status, school-based barriers, teacher-based barriers and student based barriers are found highly significant with a Pvalue of $<0.0001,0.001$, and 0.004 respectively.

As to length of service, teacher-based barriers and school-based barriers are found highly significant and studentbased barriers is found significant. As to educational attainment, only school-based barriers is found significant with a P-value of 0.020 .

Table 26 presents the CPC-respondents assessment on the relationship between CPC-related factors and barriers to bullying intervention. The data reveals that the CPC-related factors have found no significant relationship to barriers in bullying intervention. As shown in the result, all P-value is greater than 0.05.

Table 26:-Relationship between the Child Protection Committee - Related Factors and Barriers to Bullying Interventions

\begin{tabular}{|lcccccccccc|}
\hline $\begin{array}{c}\text { CPC-respondents' } \\
\text { assessment of barriers to } \\
\text { bullying interventions }\end{array}$ & Age & & Gender & Civil Status & $\begin{array}{c}\text { Length of } \\
\text { Service }\end{array}$ & $\begin{array}{c}\text { Educational } \\
\text { Attainment }\end{array}$ \\
\cline { 2 - 10 } & & P-value & $r$ & P-value & $r$ & P-value & $r$ & P-value & $r$ & P-value \\
\hline Student-based barriers & 0.085 & 0.083 & -0.077 & 0.152 & 0.029 & 0.586 & 0.04 & 0.409 & 0.082 & 0.087 \\
\hline Teacher-based barriers & 0.056 & 0.256 & -0.05 & 0.354 & -0.009 & 0.861 & -0.027 & 0.587 & -0.023 & 0.642 \\
\hline School-based barriers & 0.051 & 0.29 & -0.08 & 0.126 & 0.002 & 0.963 & 0.008 & 0.869 & 0.015 & 0.742 \\
\hline Community-based barriers & 0.035 & 0.478 & -0.067 & 0.219 & -0.049 & 0.371 & 0.008 & 0.079 & 0.03 & 0.534 \\
\hline
\end{tabular}

Several programs intended to recognize, prevent, and intervene in bullying behavior have been developed and replicated in schools (Farrington \& Ttofi, 2009; Merrell, Guelder, Ross, \& Isava, 2008). These include, but are not limited to, adult training programs, antibullying campaigns, restorative justice, and intervention programs that focus on individuals, small groups, classrooms, and whole schools.

Such approaches often include a standard set of materials and instructions to be delivered by selected staff, for specified students, and for specified periods of time. Successful bullying prevention efforts in schools should consider a range of contributing factors and facilitate active involvement from families and the community. 
Table 27 presents the teacher-respondents assessment on the relationship between Teacher-related factors and responses to school-based bullying. The data reveals that as to age, Constructive-Direct responses and PunitiveDirect response are found highly significant with a P-value of 0.001 and 0.005 respectively. As to gender, the result shows that Punitive-Indirect responses have found significant, generating a chi-square value $\left(\mathrm{X}^{2}\right)$ of 13.615 with a degrees of freedom (df) of 6 and a P-value of 0.034 .

Table 27:-Relationship between the Teacher- Related Factors and their Responses to School- Based Bullying

\begin{tabular}{|c|c|c|c|c|c|c|c|c|}
\hline \multirow[t]{2}{*}{$\begin{array}{c}\text { Teacher.respondents responses' } \\
\text { to schoolbased bullying }\end{array}$} & Age & \multicolumn{3}{|c|}{ Gender } & \multicolumn{2}{|c|}{ Civil Status } & $\begin{array}{l}\text { Lengith of } \\
\text { Service }\end{array}$ & $\begin{array}{l}\text { Educational } \\
\text { Attainment } \\
\end{array}$ \\
\hline & I P.value & $x^{2}$ & $d f$ & P.value & $x^{2}$ & df Pralue & I P.value & P P.value \\
\hline & 0.0790 .000 & 16.919 & 15 & 324 & 167.32 & $45<0.00$ & $0.0680 .000^{1+*}$ & $0.021 \quad 0.43$ \\
\hline & $\begin{array}{lll}0.03 & 0.164 \\
\end{array}$ & 3.134 & 9 & 0.559 & 86.195 & $27 \quad<0.00$ & $\begin{array}{lll}0.026 & 0.223 \\
\end{array}$ & $0.032 \quad 0.23$ \\
\hline & $0.0590 .005^{* t}$ & 12.021 & 13 & 0.526 & 49.79 & $\begin{array}{ll}22 & 0.115 \\
2\end{array}$ & $0.0510 .015^{*}$ & $0.045 \quad 0.0$ \\
\hline & & & 6 & & & 18 & & \\
\hline
\end{tabular}

As to civil status, Constructive-Direct responses and Punitive-Direct response are found highly significant with generating a chi-square value $\left(\mathrm{X}^{2}\right)$ of 167.32 and 86.195 with a degrees of freedom (df) of 45 and 27 and both Pvalue of $<0.0001$ respectively. As to length of service, Constructive-Direct responses is found highly significant with a P-value of 0.001 and Punitive-Direct response is found significant with a P-value of 0.15 . As to educational attainment, no responses is found significant, as shown in the table all $\mathrm{P}$-value is greater than 0.05 .

Table 28 presents the CPC-respondents assessment on the relationship between CPC-related factors and barriers to bullying intervention. The data reveals that the CPC-related factors have found no significant relationship to responses to school-based bullying, as shown in the result, all P-value is greater than 0.05 .

Table 28:-Relationship between the CPC- Related Factors and their Responses to School-Based Bullying

\begin{tabular}{|c|c|c|c|c|c|c|c|c|c|c|c|c|}
\hline \multirow[t]{2}{*}{$\begin{array}{l}\text { CPC.respondents responses' to } \\
\text { school-based bullying }\end{array}$} & \multicolumn{2}{|c|}{ Age } & \multicolumn{3}{|c|}{ Gender } & \multicolumn{3}{|c|}{ Civil Status } & \multicolumn{2}{|c|}{$\begin{array}{l}\text { Length of } \\
\text { Service }\end{array}$} & \multicolumn{2}{|c|}{$\begin{array}{l}\text { Eductional } \\
\text { Attainment }\end{array}$} \\
\hline & r & P.value & $x^{2}$ & df & P.value & $x^{2}$ & df & P.value & 1 & P.value & & \\
\hline & 0.02 & & 15.1 & 13 & & 30.099 & 26 & & 0.021 & 0 & 0.058 & \\
\hline & & & 8.991 & & & 20.054 & 14 & & & & 0.0 & 0.5 \\
\hline & & 0.443 & 12.8 & & & 14.065 & 22.000 & 0.899 & 0.016 & 0.750 & .0 .063 & 0.3 \\
\hline & & & & & & 7.195 & 12 & 0.844 & & 24 & & \\
\hline
\end{tabular}

Table 29 presents the teacher-respondents assessment on the relationship between barriers in bullying interventions and teachers responses to school-based bullying. The data reveals that as to student barriers, all responses is considered by teacher-respondents as highly significant with a P-value of $<0.0001$. As to teacher-based barriers and school-based barriers, Punitive-Direct responses is found significant both with a P-value of $<0.0001$. As to Community-based barriers, all responses is considered by teacher-respondents as highly significant with a P-value of $<0.0001$.

Interestingly, Marshalls in 2012 study noted that no systematic relationships emerged between teachers"e selfreported responses to bullying and perceived barriers to intervention. As such, regardless of their perceived 
obstacles, teachers reported responding to bullying using the same strategies. Teachers in this study clearly expressed a desire to decrease bullying, as well as frustration and concern regarding the numerous obstacles impeding intervention. Despite their ability to identify and articulate these barriers, teachers continued to implement similar responses despite their oftentimes perceived ineffectiveness (Marshalls, 2012).

Table 29:-Relationship between the Barriers in Bullying Interventions and Teachers' Responses to School-Based Bullying

\begin{tabular}{|lcccccccc|}
\hline $\begin{array}{l}\text { Teacher-respondents responses' to } \\
\text { barriers to bullying interventions }\end{array}$ & $\begin{array}{c}\text { Student-based } \\
\text { barriers }\end{array}$ & \multicolumn{2}{c}{$\begin{array}{c}\text { Teacher-based } \\
\text { barriers }\end{array}$} & \multicolumn{2}{c|}{$\begin{array}{c}\text { School-based } \\
\text { barriers }\end{array}$} & \multicolumn{2}{c|}{$\begin{array}{c}\text { Community-based } \\
\text { barriers }\end{array}$} \\
\cline { 2 - 9 } & \multicolumn{1}{c}{ P-value } & $r$ & P-value & $r$ & P-value & $r$ & P-value \\
\hline Constructive-Direct Responses & $0.141<0.0001^{* *}$ & -0.046 & 0.082 & -0.021 & 0.425 & 0.260 & $<0.0001^{* *}$ \\
\hline Constructive-Indirect Responses & 0.131 & $<0.0001^{* *}$ & -0.048 & 0.071 & -0.038 & 0.146 & 0.245 & $<0.0001^{* *}$ \\
\hline Punitive-Direct Responses & $0.128<0.0001^{* *}$ & 0.184 & $0.000^{* *}$ & 0.216 & $0.000^{* *}$ & 0.201 & $<0.0001^{* *}$ \\
\hline Punitive-Indirect Responses & 0.132 & $<0.0001^{* *}$ & -0.021 & 0.433 & 0.001 & 0.973 & 0.210 & $<0.0001^{* *}$ \\
\hline
\end{tabular}

Legend: ** highly significant

These findings suggested that although participating teachers were clearly concerned about bullying, they felt incompetent and limited in their ability to influence the multiple systems in which bullying was maintained. In addition, the aforementioned lack of preparation in terms of bullying interventions may have contributed to teachers employing the same anti-bullying strategies regardless of their perceived barriers. Providing alternative strategies for teachers to use when responding to bullying is essential. Without other options, many teachers are likely to continue implementing the same (often perceived ineffective) responses, which in turn may lead to feelings of despondency and ultimately inaction in terms of bullying intervention.

Table 30 presents the CPC-respondents assessment on the relationship between barriers in bullying interventions and CPC responses to school-based bullying. The data reveals that as to student barriers, Constructive-Direct and Constructive-Indirect are considered by teacher-respondents as highly significant with a P-value of $<0.0001$ and 0.003 respectively.

Table 30:-Relationship between the Barriers in Bullying Interventions and CPC Responses to School-Based Bullying

\begin{tabular}{|lcccccccc|}
\hline $\begin{array}{c}\text { CPC-respondents responses' to } \\
\text { barriers to bullying interventions }\end{array}$ & $\begin{array}{c}\text { Student-based } \\
\text { barriers }\end{array}$ & \multicolumn{2}{c}{$\begin{array}{c}\text { Teacher-based } \\
\text { barriers }\end{array}$} & $\begin{array}{c}\text { School-based } \\
\text { barriers }\end{array}$ & \multicolumn{2}{c|}{$\begin{array}{c}\text { Community-based } \\
\text { barriers }\end{array}$} \\
\cline { 2 - 9 } & $\mathrm{r}$ & P-value & $\mathrm{r}$ & P-value & $\mathrm{r}$ & P-value & $\mathrm{r}$ & P-value \\
\hline Constructive-Direct Responses & 0.370 & $<0.0001^{* *}$ & 0.116 & 0.060 & 0.321 & $<0.0001^{* *}$ & 0.465 & $<0.0001^{\text {** }}$ \\
\hline Constructive-Indirect Responses & 0.184 & $0.003^{* *}$ & 0.001 & 0.988 & 0.154 & $0.013^{*}$ & 0.261 & $<0.0001^{\text {** }}$ \\
\hline Punitive-Direct Responses & 0.104 & 0.920 & 0.345 & $0.000^{* *}$ & 0.536 & $<0.0001^{* *}$ & 0.351 & $<0.0001^{\text {** }}$ \\
\hline bullying interventions & 0.098 & 0.113 & 0.097 & 0.118 & 0.218 & $<0.0001^{* *}$ & 0.279 & $<0.0001^{\text {** }}$
\end{tabular}

Legend: * significant ** highly significant

As to teacher-based barriers, Punitive-Direct responses is highly significant with a P-value of $<0.0001$. As to schoolbased barriers, Constructive-Direct responses, Punitive-Direct responses-Indirect are all found highly significant with a P-value of $<0.0001$ and Constructive-Indirect is found significant with a P-value of 0.13 . As to Communitybased barriers, all responses is considered by CPC-respondents as highly significant with a $\mathrm{P}$-value of $<0.0001$. 
In a study conducted by Marshalls in 2012, Sociocultural factors, community-related factors in this study (e.g., parentse reactions to bullying, prevalence of bullying occurring outside of school, differing behavioral expectations and perceptions of bullying among community members) also led to barriers for the majority of participating teachers.

These results highlight the need for participation from families and community partners when developing and implementing anti-bullying programs (e.g., Olweus \& Limber, 2010; Swearer et al., 2009). As espoused by Craig and colleagues (2010), "to enhance the potential for change, connections with the community can be established to extend an understanding of bullying and to promote consistent responses to bullying problems throughout the broader community". Finally, individual student factors also were reported as a common barrier by many teachers. Prior studies have found that teachers' responses to bullying were influenced by various individual characteristics (e.g., gender, social status, developmental and personality factors) of involved students (e.g., Mishna et al., 2005; Nesdale \& Pickering, 2006). Similarly, the findings from this study suggest that when developing anti-bullying programs and professional learning efforts for teachers, scholars and educators need to carefully consider the various individual student factors contributing to teachers' confidence and ability to implement successful responses.

In combination, school-based barriers and community-based barriers have highly significant effect to bullying intervention programs and strategies both with a P-value of $<0.0001$. Singly, school-based barriers have highly significant effect in bullying intervention programs with a P-value of $<0.0001$. Community-based barriers have highly significant effect in bullying intervention program and strategies both with a P-value of $<0.0001$ as assessed by teacher-respondents.

The result further reveals, as to CPC-respondents, in combination, student-based barriers have high significant influence in bullying intervention programs with a P-value of 0.001 , teacher-based barriers have high significant influence on both bullying intervention programs and strategies with a P-value of $<0.000$ and 0.003 respectively. School-based barriers have significant influence bullying intervention programs with a P-value of 0.038 and highly significant influence to bullying intervention strategies with a P-value of $<0.0001$. Singly, student-based barriers have significant influence in bullying intervention programs with a P-value of 0.027. Teacher-based barriers have significant influence in bullying intervention strategies with a P-value of 0.016. School-based barriers have highly significant influence in bullying intervention strategies.

The conclusions drawn by Bradshaw, 2015 study have been somewhat mixed, with some researchers concluding that prevention programs have limited impact (e.g., Ferguson et al., 2007; Merrell et al., 2008), and others interpreting the literature more favorably (e.g., Farrington \& Ttofi, 2009; Ttofi \& Farrington, 2011).

Because of its comprehensiveness and rigor. Applying the Campbell Systematic Review procedures, Farrington and Ttofi (2009) reviewed 44 rigorous program evaluations and RCTs. The majority of the studies reviewed were conducted outside of the United States or Canada and over a third of these programs were based in part on the work of Olweus (1993). Taken together, Farrington and Ttofi (2009) found that the programs, on average, were associated with a $20 \%$ to $23 \%$ decrease in perpetration of bullying, and a $17 \%$ to $20 \%$ decrease in victimization.

Some packaged anti-bullying programs have evidence of moderate levels of success in reducing bullying behavior. The success of these programs is often dependent on the intensity and duration of the program, which must be longlasting to have a significant impact (Ttofi \& Farrington, 2011). Single, stand-alone bullying prevention programs, however, tend not to be optimally effective or sustainable because they: $\bullet$ are fragmented; $\bullet$ are seen as another task to do by only selected individuals; - view bullying as an issue affecting a subset of students instead of the larger school context; - rely on strategies that have proven ineffective, or even counterproductive, such as punitive discipline and zero tolerance policies; - do not fully consider the unique characteristics of the local context, including family and community factors; and $\bullet$ lack coordination between multiple grade levels and among faculty and staff. In contrast to the more optimistic conclusions based on the rigorous review by Farrington and Ttofi (2009), some of the other systematic reviews of bullying prevention programs have generally been less favorable (e.g., Ferguson et al., 2007; Merrell et al., 2008). For example, Merrell et al. conducted a meta-analysis of 16 schoolbased bullying intervention studies and concluded that the interventions only produced a significant and "meaningful" impact on one third of the bullying-related outcomes examined. 
Taken together, the research generally suggests that bullying prevention programs can produce meaningful impacts on bullying- related outcomes; however, as will be discussed further, issues of implementation quality and poor compliance with the prevention model likely compromise the effects observed on bullying behavioral outcomes in real-world applications (Domitrovich et al., 2008; Bradshaw, 2015

\section{Conclusions:-}

Age as a teacher-based barrier is found highly significant. Civil status, school-based barriers, teacher-based barriers and student based barriers are found highly significant, As to length of service, teacher-based barriers and schoolbased barriers are found highly significant and student-based barriers is found significant, as to educational attainment, only school-based barriers is found significant

Age, Constructive-Direct responses and Punitive-Direct response were found to have highly significant relationship. Civil status, Constructive-Direct responses and Punitive-Direct response were found to have highly significant relationship, as to length of service, Constructive-Direct responses were found to have highly significant relationship and Punitive-Direct responses were found to have significant relationship ,.

CPC-related factors were found to have no significant relationship to responses to school-based bullying. As to student barriers, all responses were found to have highly significant relationship. As to teacher-based barriers and school-based barriers, Punitive-Direct responses is found significant. As to Community-based barriers, all responses were found to have highly significant relationship.

As to student barriers, Constructive-Direct and Constructive-Indirect responses were found to have highly significant relationship. As to teacher-based barriers, Punitive-Direct responses were found to have highly significant relationship. As to school-based barriers, Constructive-Direct responses, Punitive-Direct responsesPunitive-Indirect responses were all found to have highly significant relationship and Constructive-Indirect responses were found to have significant relationship. As to Community-based barriers, all responses were found to have highly significant relationship.

School-based barriers and community-based barriers have found significant effect on bullying intervention programs and strategies. Community-based barriers significantly affect bullying intervention programs and strategies. As to CPC-respondents, in combination, student-based barriers were found to have highly significant effect on bullying intervention programs. Teacher-based barriers significantly effect on both bullying intervention programs and strategies. School-based barriers were found to have significant effect on bullying intervention programs and highly significant effect to bullying intervention strategies. Singly, student-based barriers were found to have significant effect on bullying intervention programs. Teacher-based barriers were found to have significant effect on bullying intervention strategies. School-based barriers were found to have highly significant effect on bullying intervention strategies.

\section{Recommendations:-}

Towards the barriers in the implementation of school-based bullying intervention programs and strategies in public secondary schools in a certain division of Laguna the following recommendations are given:

1. Provide comprehensive training to all teachers and staff about bullying intervention. Empower teachers and staff with effective strategies to confront bullying on the spot.

2. Strengthen and promote home visitation program, values formation, student and parents' orientation. Parents' participation is an important to bullying intervention.

3. Develop a bullying coordinating committee to develop school anti-bullying policies and oversee implementation of anti-bullying programs

4. Increase awareness and knowledge of bullying by increasing student reporting, monitoring and track bullying behaviors, survey all students to determine bullying problem in school.

5. More research is needed in order to determine what specific factors inherent in the classroom environment might influence bullying behavior. Researcher may pursue studies related to the impact of bullying programs and intervention studies which use solid experimental designs, and which measure impact on actual bullying behaviors as well as perceptions and knowledge, are particularly needed. 


\section{References:-}

1. Altun, S. \& Baker, O. School Violence: a qualitative study. Precede Social and Behavioral Sciences, 2, 3165 - 3169. (2010)

2. American Education Research Association 2013. "Prevention of Bullying in Schools, Colleges, and Universities. Research Report and Recommendation. Washington DC.

3. Ancho, I. and S. Park (2013). School violence in the Philippines: A study on programs and policies. Advance Science and Technology Letters Vol. 36 (Education 2013) pp. 27-31 http:// dx doi.org/10-14257.07

4. Bauman, S., \& Del Rio, A. (2006). Pre service teachers"e responses to bullying scenarios: Comparing physical, verbal, and relational bullying. Journal of Educational Psychology, 98(1), 219-231. doi:10.1037/00220663.98.1.219

5. Bauman, S., \& Hurley, C. (2005). Teachers ${ }^{e e}$ attitudes and beliefs about bullying. Journal of School Violence, 4(3), 49-61. doi:10.1300/J202v04n03_05

6. Bauman, S., Cross, D., \& Walker, J. (2013). Principles of cyberbullying research: Definitions, measures, and methodology. New York, NY: Routledge.

7. Bauman, S., Rigby, K., \& Hoppa, K. (2008). U.S. teachersee and school counselors ${ }^{\text {ee }}$ strategies for handling school bullying incidents. Educational Psychology, 28(7), 837-856. doi:10. 1080/01443410802379085

8. Bickmore, K. Policies and Programming for Safe Schools: are "Anti-bullying" Approaches Impeding Education for Peacebuilding? Educational Policy, 25, 648 - 687. (2011)

9. Boulton, M. J., Trueman, M., \& Murray, L. (2008). Associations between peer victimization, fear of future victimization and disrupted concentration on class work among junior school pupils. British Journal of Educational Psychology, 78, 473-489. doi:10.1348/ 000709908X320471

10. Bradshaw, C. P. (2013). Preventing bullying through positive behavioral interventions and supports (PBIS): A multi-tiered approach to prevention and integration. Theory into Practice, 52, 288-295. http://dx.doi .org/10.1080/00405841.2013.829732

11. Bradshaw, C. P. (2014). The role of families in preventing and buffering the effects of bullying. Journal of the American Medical Association Pediatrics,168,991-993.http://dx.doi.org/10.1001/jamapediatrics.2014 .1627

12. Bradshaw, C. P. (2015). Translating research to practice in bullying prevention. American Psychologist, 70, 322-332. http://dx.doi.org/ 10.1037/a0039114

13. Bradshaw, C. P., C. W. Koth, L. A. Thornton, and P. J. Leaf. 2009. "Altering school climate through schoolwide Positive Behavioral Interventions and Supports: Findings from a group-randomized effectiveness trial." Prevention Science 10:100-115.

14. Bradshaw, C. P., Sawyer, A. L., \& O’ Brennan, L. M. (2007). Bullying and peer victimization at school: Perceptual differences between students and school staff. School Psychology Review, 36, 361-382.

15. Cornell, D., \& Limber, S. P. (2015). Law and policy on the concept of bullying at school. American Psychologist, 70, 333-343. http://dx.doi .org/10.1037/a0038558

16. Craig, W. M., Pepler, D. J., Murphy, A., \& McCuaig-Edge, H. (2010). What works in bullying prevention? In E. M. Vernberg \& B. K. Biggs (Eds.), Preventing and treating bullying and victimization (pp. 215-241). New York, NY: Oxford

17. Cullen, D. (2009). Columbine. New York, NY: Twelve Hachette Book Group.

18. Cyberbullying and School Bullying. Journal of Student Well Being, 1, 15-33

19. Domitrovich, C. E., Bradshaw, C. P., Poduska, J., Hoagwood, K., Buckley, J., Olin, S., . Ialongo, N. S. (2008). Maximizing the implemen- tation quality of evidence-based preventive interventions in schools: A conceptual framework. Advances in School Mental Health Promotion: Training and Practice. Research Policy, 1, 6-28.

20. Durlak, J. A., Weissberg, R. P., Dymnicki, A. B., Taylor, R. D., \& Schellinger, K. B. (2011). The impact of enhancing students' social and emotional learning: A meta-analysis of school-based universal inter- ventions. Child Development, 82, 405-432. http://dx.doi.org/10.1111/j .1467-8624.2010.01564.x

21. Ericksen et. al. 2012. The Effects of Bullying in Elementary School. IZA DP No. 6718.

22. Espelage, D. L. (2012). Bullying prevention: A research dialogue with Dorothy Espelage. Prevention Researcher, 19(3), 17-19.

23. Espelage, D. L., \& Swearer, S. M. (2008). Current perspectives on linking school bullying research to effective prevention strategies. In T. W. Miller (Ed.), School violence and primary prevention (pp. 335-353). Secaucus, NJ: Springer. http://dx.doi.org/10.1007/978-0-387-77119-9_17

24. Espelage, D. L., \& Swearer, S. M. (2011). Bullying in North American schools (2nd ed.). New York, NY: Routledge. 
25. Espelage, D. L., Low, S., \& De La Rue, L. (2012). Relations between peer victimization subtypes, family violence, and psychological outcomes during adolescence. Psychology of Violence, 2(4), 313-324. doi:10.1037/a0027386

26. Family Code of the Philippines Article 218

27. Farrington, D. P., \& Ttofi, M. M. (2009). School-based programs to reduce bullying and victimization (Campbell Systematic Reviews No. 6). Oslo, Norway: Campbell Corporation. http://dx.doi.org/10.4073/csr .2009 .6

28. Ferguson, C. J., Miguel, C. S., Kilburn, J. C., \& Sanchez, P. (2007). The effectiveness of school-based antibullying programs: A meta-analytic review. Criminal Justice Review, 32, 401-414. http://dx.doi.org/ $10.1177 / 0734016807311712$

29. Flores and Sy the Philippine Star 2013

30. Godfrey, R. (2005). Under the bridge: The true story of the murder of Rina Virk. New York: Simon \& Schuster.

31. Holt, M. K., Raczynskib, K., Frey, K. S., Hymel, S., \& Limber, S. P. (2013). School and community-based approaches for preventing bullying. Journal of School Violence, 12, 238-252. http://dx.doi.org/10.1080/ 15388220.2013.792271

32. Holt, M., Keyes, M., \& Koenig, B. (2011). Teachers' attitudes toward bullying. In D. Espelage \& S. Swearer (Eds.), Bullying in North American schools (2nd ed., pp. 119-131). New York, NY: Routledge.

33. Hymel, S. and Swearer, S. (2015). Four decades of research on school bullying. American Psychological Association. Vol. 70 No. 4 293-299

34. IRR, RA 10627. Posted December 13, 2013. Retrieved August 28, 2015

35. Jimerson, S., Swearer, S. M., \& Espelage, D. L. (2010). The handbook of bullying in schools: An international perspective. New York, NY: Routledge.

36. Limber, S. P. (2011). Implementation of the Olweus Bullying Prevention Program in American schools: Lessons learned from the field. In D. Espelage \& S. Swearer (Eds.), Bullying in North American schools (2nd ed., pp. 291-305). New York, NY: Routledge.

37. Marshall, M. (2012). Teachers' perceived Barriers to effective bullying intervention. Dissertation. Georgia State University. Counseling and Psychological Services http:// scholarship work.gsu.edu/cps_diss/70

38. Marshall, M. L., Varjas, K., Meyers, J., Graybill, E. C., \& Skoczylas, R. B. (2009). Teacher responses to bullying: Self-reports from the front line. Journal of School Violence, 8(2), 136-158. doi:10.1080/15388220802074124

39. Merrell, K. W., Gueldner, B. A., Ross, S. W., \& Isava, D. M. (2008). How effective are school bullying intervention programs? A meta-analysis of intervention research. School Psychology Quarterly, 23, 26-42. http:// dx.doi.org/10.1037/1045-3830.23.1.26

40. Meyer-Adams, N., \& Conner, B. T. (2008). School violence: Bullying behaviors and the psychosocial school environment in middle schools. Children \& Schools, 30, 211-221. doi:10.1093/cs/30.4.211

41. Mishna, F., Scarcello, I., Pepler, D., \& Wiener, J. (2005). Teachers understanding of bullying. Canadian Journal of Education, 28(4), 718-738. doi:10.2307/4126452

42. National Association of School Psychologists. (2012). Bullying prevention and intervention in schools [Position statement]. Bethesda, MD: Author.

43. Nesdale, D., \& Pickering, K. (2006). Teachersee reactions to children's aggression. Social Development, 15, 109-127.

44. Olweus, D. (1993). Bullying at school. Oxford, UK: Blackwell. Rodkin, P. C., Espelage, D. L., \& Hanish, L. D. (in press). A relational perspective on the social ecology of bullying. American Psychologist.

45. Olweus, D. (2011). Bullying at School and Later Criminality: Finding from three Swedish community samples of males. Criminal Behavior and Mental Health, Vol. 21 (2)

46. Olweus, D. 2005. "A useful evaluation design, and effects of the Olweus Bullying Prevention Program." Psychology, Crime, and Law 11:389-402 http://dx.doi.org/10.1080/10683160500255471

47. Olweus, D., \& Limber, S. P. (2010). The Olweus Bullying Prevention Program: Implementation and evaluation over two decades. In S. R. Jimerson, S. M. Swearer, \& D. L. Espelage (Eds.), the handbook of school bullying: An international perspective (pp. 377-402). New York, NY: Routledge.

48. Pepler, D., Craig, W., \& O'Connell, P. (2010). Peer processes in bullying: Informing prevention and intervention strategies. In S. R. Jimerson, S. M. Swearer, \& D. L. Espelage (Eds.), Handbook of bullying in schools: An international perspective (pp. 469-479). New York, NY: Routledge.

49. Philippine 1987 Constitution Article XV Section 3 subsection 3 and 4

50. PWU-CWC-UNICEF 2009 "Toward a child friendly Education Environment” for Plan Philippines 
51. Ross, S. W., R. H. Horner, and B. Stiller. 2008. Bully Prevention in Positive Behavior Support. Eugene, OR: Educational and Community Supports, University of Oregon. Ross, S. W., and R. H. Horner. 2009. "Bully prevention in positive behavior support." Journal of Applied Behavior Analysis 42:747-759.

52. Swearer, S. M., \& Hymel, S. (2015). Understanding the psychology of bullying: Moving toward a socialecological diathesis-stress model. American Psychologist, 70, 344-353. http://dx.doi.org/10.1037/ a0038929

53. Swearer, S. M., Espelage, D. L., \& Napolitano, S. A. (2009). Bullying prevention \& intervention: Realistic strategies for schools. New York, NY: The Guilford Press.

54. Swearer, S. M., Espelage, D. L., Koenig, B., Berry, B., Collins, A., \& Lembeck, P. (2012). A social-ecological model of bullying prevention and intervention in early adolescence. In S. R. Jimerson, A. B. Nickerson, M. J. Mayer, \& M. J. Furlong (Eds.), the handbook of school violence and school safety: International research and practice. (pp. 333-355) New York, NY: Routledge.

55. Swearer, S. M., Espelage, D. L., Vaillancourt, T., \& Hymel, S. (2010). What can be done about school bullying? Linking research to educational practice. Educational Researcher, 39, 38-47. http://dx.doi.org/ $10.3102 / 0013189$ X09357622

56. Swearer, S. M., Wang, C., Collins, A., Strawhun, J., \& Fluke, S. (2014). Bullying: A school mental health perspective. In M. D. Weist, N. A. Lever, C. P. Bradshaw, \& J. Owens (Eds.), Handbook of school mental health: Advancing practice and research (2nd ed., pp. 341-354). New York, NY: Springer. http://dx.doi.org/10.1007/978-1-4614-7624-5_25

57. Ttofi, M. M., \& Farrington, D. P. (2011). Effectiveness of school-based programs to reduce bullying: A systematic meta-analytic review. Journal of Experimental Criminology, 7, 27-56. http://dx.doi.org/10.1007/ s11292-010-9109-1

58. Ttofi, M. M., Eisner, M., \& Bradshaw, C. P. (2014). What have we learned from systematic reviews of bullying prevention programs? A synthesis of current evaluation research. In G. Bruinsma \& D. Weisburd (Eds.), Encyclopedia of criminology and criminal justice (pp. 231-242). New York, NY: Springer-Verlag. http://dx.doi.org/10.1007/978-1-4614- 5690-2_585

59. Waasdorp, T. E., Bradshaw, C. P., \& Duong, J. (2011). The link between parents' perceptions of the school and their responses to school bullying: Variation by child characteristics and the forms of victimization. Journal of Educational Psychology, 103, 324-335. http://dx.doi.org/ 10.1037/a0022748

60. Waasdorp, T. E., Bradshaw, C. P., \& Leaf, P. J. (2012). The impact of school wide positive behavioral interventions and supports on bullying and peer rejection: A randomized controlled effectiveness trial. Archives of Pediatrics \& Adolescent Medicine, 166(2), 149-156. doi:10.1001/archpediatrics.2011.755

61. Waasdorp, T. E., Pas, E. T., O’Brennan, L. M., \& Bradshaw, C. P. (2011). A multilevel perspective on the climate of bullying: Discrepancies among students, school staff, and parents. Journal of School Violence, 10, 115-132. http://dx.doi.org/10.1080/15388220.2010.539164

62. Yoon, J., Bauman, S., Choi, T., \& Hutchinson, A. S. (2011). How South Korean teachers handle an incident of school bullying. School Psychology International, 32(3), 312-329. doi:10.1177/0143034311402311 